\title{
The Energy Content and Composition of Meals Consumed after an Overnight Fast and Their Effects on Diet Induced Thermogenesis: A Systematic Review, Meta-Analyses and Meta-Regressions
}

\author{
Angelica Quatela ${ }^{1}$, Robin Callister ${ }^{2}$, Amanda Patterson ${ }^{1}$ and Lesley MacDonald-Wicks ${ }^{1, *}$ \\ 1 Discipline of Nutrition and Dietetics, School of Health Sciences, The University of Newcastle, \\ University Drive, Callaghan 2308, NSW, Australia; angelica.quatela@uon.edu.au (A.Q.); \\ amanda.patterson@newcastle.edu.au (A.P.) \\ 2 Priority Research Centre for Physical Activity and Nutrition, School of Biomedical Sciences and Pharmacy, \\ The University of Newcastle, University Drive, Callaghan 2308, NSW, Australia; \\ robin.callister@newcastle.edu.au \\ * Correspondence: lesley.wicks@newcastle.edu.au; Tel.: +61-2-4921-6646
}

Received: 22 July 2016; Accepted: 18 October 2016; Published: 25 October 2016

\begin{abstract}
This systematic review investigated the effects of differing energy intakes, macronutrient compositions, and eating patterns of meals consumed after an overnight fast on Diet Induced Thermogenesis (DIT). The initial search identified 2482 records; 26 papers remained once duplicates were removed and inclusion criteria were applied. Studies $(n=27)$ in the analyses were randomized crossover designs comparing the effects of two or more eating events on DIT. Higher energy intake increased DIT; in a mixed model meta-regression, for every $100 \mathrm{~kJ}$ increase in energy intake, DIT increased by $1.1 \mathrm{~kJ} / \mathrm{h}(p<0.001)$. Meals with a high protein or carbohydrate content had a higher DIT than high fat, although this effect was not always significant. Meals with medium chain triglycerides had a significantly higher DIT than long chain triglycerides (meta-analysis, $p=0.002$ ). Consuming the same meal as a single bolus eating event compared to multiple small meals or snacks was associated with a significantly higher DIT (meta-analysis, $p=0.02$ ). Unclear or inconsistent findings were found by comparing the consumption of meals quickly or slowly, and palatability was not significantly associated with DIT. These findings indicate that the magnitude of the increase in DIT is influenced by the energy intake, macronutrient composition, and eating pattern of the meal.
\end{abstract}

Keywords: breakfast; meal; overnight fast; energy intake; macronutrient; diet-induced thermogenesis; thermic effect of food; meal-induced thermogenesis; resting metabolic rate

\section{Introduction}

The meal consumed after an overnight fast, generally referred to as breakfast, is often described as 'the most important meal of the day' [1] as it is believed to contribute to good health and nutrition by providing essential nutrients early in the day [2]. Skipping breakfast is associated with increased weight gain and obesity, suggesting that breakfast may be protective against weight gain $[1,3]$. Among the explanations for this protective effect of breakfast are that it stimulates the body's metabolism because it breaks the overnight fast [4], potentially contributing to increased total daily energy expenditure. The extent of this effect would depend on the diet induced thermogenesis (DIT) response to the meal consumed. Evidence supporting this proposal is limited and contradictory [5,6]. Alternatively, eating breakfast may result in decreased energy consumption during the rest of the day, however the evidence available from previous trials in this area is also limited and contradictory [1]. 
Obesity is a major public health concern internationally with an estimated $13 \%$ and $39 \%$ of adults worldwide being obese or overweight respectively [7], and 63\% being either overweight or obese in Australia [8]. Breakfast is often advocated as a strategy to prevent weight gain. However, a recent review [3] and a separate meta-analysis [1] found that there is very limited evidence regarding the effects of breakfast on preventing weight gain [1,3], and as most of the studies conducted have only been observational, there has been little investigation into the mechanisms by which breakfast may exert effects on preventing obesity [1]. Both of these reviews found insufficient evidence to support consumption of breakfast for obesity prevention and suggested that further research in this area is required $[1,3]$.

Given the suggested importance of breakfast in the health arena, there are surprisingly few systematic reviews (SRs) consolidating the evidence of its effects on obesity prevention $[1,9,10]$ and no SR and/or meta-analyses have investigated the effect of consuming breakfast on accelerating DIT, which may contribute to a reduced risk of weight gain. Most studies investigating the effects of food on DIT investigate these effects after an overnight fast. Therefore these studies provide insights into the possible effects of breakfast on DIT although the meals used in these studies may not be typical of those eaten as breakfast and their goal may not have been to investigate the effects of breakfast.

No SRs have been conducted to compare the effects of meals after an overnight fast of varying macronutrient or micronutrient compositions, or different energy densities, on DIT. This highlights the need for a SR to be conducted in this area to address the lack of cohesive evidence of the role of these meals on DIT. This is of particular interest because even small changes in DIT may have significant effects on body weight and/or body composition over the longer term. Specifically, it has been suggested that an imbalance of 10-20 kcal/day can result in $0.5-1 \mathrm{~kg}$ of weight gain annually [11].

The primary question in this paper is whether there is any difference in the effects on DIT of meals consumed after an overnight fast of varying energy intake or macronutrient composition. Secondary questions are whether there is any difference in the effects on DIT if the same meal content is consumed using different eating patterns, such as a bolus meal versus repeated snacking, the effects of fast versus slow consumption of food, and whether food palatability of this meal has an effect on DIT. The outcomes of this SR will assist in better understanding the role of meal or snack consumption after an overnight fast on DIT and help to inform further research on the potential role of breakfast in health, as well as obesity prevention, treatment, and management.

\section{Materials and Methods}

The SR protocol was published in 'Prospero' (CRD42014009030). Methodological decisions about the review process were made a priori.

\subsection{Search}

With the assistance of a research librarian, four databases were searched: Cochrane (from 1992 to 14 May 2014), Cinahl (from 1937 to 14 May 2014), Embase (from 1947 to 14 May 2014), and Medline (from 1946 to 14 May 2014), and were then updated on the 23 February 2016 in order to capture the studies published between 14 May 2014 and 23 February 2016. This search used the following keywords: breakfast, morning meal, diet induced thermogenesis, thermogenesis, meal induced thermogenesis, thermic effect of food, resting metabolic rate, postprandial or post prandial metabolism, postprandial or post prandial metabolic rate, postprandial or post prandial energy expenditure, resting energy expenditure, postabsorptive or post absorptive energy expenditure, postabsorptive or post absorptive metabolic rate, basal metabolism, basal metabolic rate, and metabolic rate. For Embase, Medline, and Cinahl, limits were applied to include only human studies, those in English, and those conducted in adults. The Cochrane database did not allow these limits, however the word 'adults' was added as a keyword in order to limit the search to studies performed in adults. On the 23 February, this SR search was also expanded by the substitution of the keyword 'morning meal' by the keyword 'meal', in order to find studies that administered a meal after an overnight fast (breakfast) but did not 
use the terms morning meal or breakfast in the article. Also the keywords 'thermic' and 'thermogenic' were added to the search to ensure studies using slightly different language were not missed.

\subsection{Eligibility Criteria}

\subsubsection{Inclusion and Exclusion Criteria}

For this review, only studies designated as level A evidence (randomized controlled trials (RCTs) and randomized crossover trials), as defined by the Academy of Nutrition and Dietetics, and with two or more eating events for comparison, were included. Studies were included if they provided a snack or a meal in the morning after participants fasted overnight. Studies were excluded if they provided infusions, injections, or capsules with the meal (e.g., saline or drug infusion, drug or placebo capsules). Interventions consisting of meals administered as enteral or intranasal or intra-gastric infusion or consisting of supplements instead of meals (e.g., protein or fat or sugar emulsions) or of meals supplemented with other components (e.g., addition of cellulose or pectin) including stimulants (e.g., caffeine, green tea, chilli, capsaicin, alcohol) were excluded. In these studies, the control meal (e.g., oral feeding or meal without stimulants) data were extracted if provided. When studies provided additional non-dietary interventions (e.g., exercise, sleep interventions), only data from the first meal consumed after an overnight fast intervention of the controlled arm were extracted.

Studies were included if they were published in English with male and/or female adult ( $\geq 18$ years old) human participants. Data from populations such as children, adolescents, athletes or exercise-trained groups, patients with chronic or acute disease, obese individuals, pregnant or lactating women, or smokers were excluded. Studies with mixed populations of healthy weight, overweight, and obese populations were included; however, studies targeting only obese subjects or a mix of overweight and/or obese participants were excluded. Studies were also excluded when the majority of the participants were obese leading to a mean or median body mass index (BMI) $\geq 30 \mathrm{~kg} / \mathrm{m}^{2}$. When studies compared specific populations (e.g., obese, pregnant women, athletes, smokers) to a control group, only data from the control group were included. The original search included all study designs, however, only RCT or randomized cross over designs were included in the analyses for this paper. Articles were excluded if they were expert opinion papers or if they described animal, in vitro, or in vivo experimental studies.

\subsubsection{Outcome Measures (Dependent Variables)}

Diet induced thermogenesis measured by indirect calorimetry was the main outcome measure. Other outcomes of interest were indirect calorimetry fasting RMR and postprandial energy expenditure.

\subsubsection{First Meal Consumed after an Overnight Fast (Independent Variables)}

The intervention was the first snack or meal of the day consumed in the morning after an overnight fast. Macronutrient compositions were described as percentages of the energy content of the meal. Energy was expressed in $\mathrm{kJ}$.

\subsubsection{Systematic Review Process}

Titles and abstracts were assessed for full text retrieval (A.Q.). Full text articles were assessed against the inclusion and exclusion criteria by two independent reviewers (A.Q. and A.P.). The quality criteria checklist for primary research of the Academy of Nutrition and Dietetics was used to assess the quality of the included studies by two independent reviewers (A.Q. and L.M.-W. or A.P.). The quality criteria tool assessed the studies for relevance and validity of the selected publications. A study was deemed positive if it met all the priority criteria, at least one of the validity criteria, and all of the relevance questions. A neutral rating indicated that most of the validity criteria were met but the study may not have met one or more of the priority criteria and/or one or more of the relevance questions. A study was rated as negative if six or more of the validity and/or priority criteria were 
rated negative. Any discrepancies between reviewers at the full text and quality stage were assessed by a fourth reviewer (R.C.) until a consensus decision was reached.

\subsubsection{Data Extraction}

The relevant data from the studies were extracted into tables (A.Q.) and evaluated for completeness (A.P., R.C., L.M.-W.). The following information was extracted: study design, significance, inclusion and exclusion criteria, country location, sample size, participant characteristics (intervention and comparator groups), recruitment, blinding used, intervention, statistical analysis, timing of measurements, dependent and independent variables, co-variates, length of follow up and results (key findings and other findings), and author conclusions.

\subsubsection{Participant Characteristics}

Participant characteristics (age, gender, BMI, fat mass (FM), and fat free mass (FFM)) were extracted when provided or calculated from the data provided. BMI was calculated using the WHO criteria as illustrated in Supplementary Materials Table S1. FM and FFM were expressed as \% of total body weight or in $\mathrm{kg}$. If only individual participant data were provided, the mean, standard deviation (SD), and standard error (SE) were calculated with the formula described in Supplementary Materials Table S1. The percentage of males in the sample was calculated $(100 \%$ indicated that only males were recruited and $0 \%$ only females).

\subsubsection{Characteristics of the Meals}

The energy content of the meals was expressed in kJ. The conversion factor of 4.184 was used to convert kcal to $\mathrm{kJ}$. When studies provided the macronutrient composition of meals only in grams, it was converted from $\mathrm{g}$ to \% of energy using the two formulas described in Supplementary Materials Table S1.

\subsubsection{Outcome Characteristics}

RMR, also known as Resting Energy Expenditure (REE), is defined as the quantity of energy used to maintain physiological function under resting conditions. DIT, also called the thermic effect of food, postprandial energy expenditure above baseline, or meal-induced thermogenesis, is defined as the increase in RMR as a result of the consumption of food or a meal $[12,13]$. DIT data were extracted in kJ and/or as the percentage of energy content of the meal (ECM) and/or as the percentage increase above baseline $(\mathrm{AB}) \mathrm{RMR}$. When the studies provided only the total postprandial energy expenditure and the $\mathrm{RMR}$, the mean DIT was obtained from the difference of the total postprandial energy expenditure in $\mathrm{kJ}$ and the RMR in kJ for the same measure of time. DIT expressed in $\mathrm{kJ}$ or as percentage of energy content was divided by the number of hours that DIT was measured, or multiplied by 60 if it was provided in $\mathrm{kJ} /$ minute, in order to provide values as $\mathrm{kJ}$ per hour or percentage per hour. The formulas described in Supplementary Materials Table S1 were used to convert DIT from one unit of measurement to another when not provided by the authors.

\subsubsection{Meta-Regressions}

The main outcome variable used in the meta-regression was DIT in $\mathrm{kJ} / \mathrm{h}$. Mixed model meta-regression was used to investigate the relationship between energy intake $(\mathrm{kJ})$ after an overnight fast and DIT $(\mathrm{kJ} / \mathrm{h})$. The first model conducted was a univariate analysis, which only included DIT $(\mathrm{kJ} / \mathrm{h})$ and $\mathrm{kJ}$ intake. The second model also included four confounding factors (percentage of males, age, BMI and hours of DIT measurement). These meta-regression models were conducted using Stata/IC 13.1 (StataCorp LP, College Station, TX, USA) and with consultant statistical support. 


\subsubsection{Meta-Analyses}

Fixed model meta-analyses were conducted in Review Manager (RevMan) to determine the mean difference in DIT $(\mathrm{kJ} / \mathrm{h})$ of pairs of comparisons. These meta-analyses were conducted with consultant statistical support.

\section{Results}

A total of 2482 papers were identified from the four databases searched; 1756 papers remained after duplicates were removed and 351 full text articles were reviewed (Figure 1). Only 27 Level A evidence studies from 26 papers (one paper described two studies [14]) were relevant to answer the review questions for this paper. Of the 26 papers, four were rated positive [15-18], none were rated negative, and the remaining 22 papers were rated neutral.

Table 1 summarizes the 27 studies for participants' characteristics and study protocols. Table 2 summarizes the interventions and outcomes of the studies. Nine studies were conducted in the USA [19-27], five in Japan [14,28-30], four in the UK [17,31-33], two in Australia [18,34], two in France [35,36], two in Denmark [15,37], one in Germany [38], one in Spain [39], and one in the Netherlands [16].The majority of the studies were not blinded, three were double blinded [14,37], and two studies were single blinded [18,24]. One study provided intervention meals for two weeks for each arm [36] whereas all other studies provided only one day interventions.

\subsection{Participant Characteristics}

A total of 350 participants were included. The participants' characteristics are described in Table 1. The participants mean ages ranged from 20 to 69.4 years. Mean BMI ranged from 18.1 to $27.8 \mathrm{~kg} / \mathrm{m}^{2}$. FM was mostly expressed in $\%$ and it ranged from $11.1 \%$ to $31.4 \%$. FFM was only described in $\mathrm{kg}$ and it ranged from 41.7 to $66.8 \mathrm{~kg}$. The sample size ranged from a minimum of four to a maximum of 29 . The majority of the studies had a sample size $<20$; only four studies had $\geq 20$ participants $[24,33,35,39]$. Fifteen studies had only males $[14,18,19,21-23,25,28,30,33-37,39]$, eight studies had only females $[14,20,24,27,29,31,32,38]$, and four studies had a mix of males and females $[15-17,26]$.

\subsection{Interventions}

All studies required participants to attend the research setting in the morning after an overnight fast. The majority of the studies required arrival at the research center after a fasting period ranging from 10 to $14 \mathrm{~h}[15,18,20,22-29,31,33-35,37,38]$. Many studies also required refraining from any exercise/physical activity or vigorous exercise either from the evening/dinner before [24,28,30,34], or from the day before $[17,19,20,29,35]$, or an even longer period of time ( $36 \mathrm{~h}$ to 3 days) $[15,18,21-23,25,37]$. Fasting RMR was then measured and the meal administered. The interventions differed in energy intake and macronutrient composition between studies. Energy intakes for meals ranged from 418 to $6276 \mathrm{~kJ}$. Carbohydrate (CHO) ranged from $0 \%$ to $90.4 \%$, protein from $1.3 \%$ to $34.0 \%$, and fat from $1.0 \%$ to $78.8 \%$ of energy intake. DIT was measured after the meal was consumed.

\subsection{Outcomes}

The mean fasting RMR measured before administering the meals ranged from 191.6 to $375.3 \mathrm{~kJ} / \mathrm{h}$. The majority of studies measured DIT periodically rather than continuously over two [34], three [22,23,29], three and a half [24,30], four [35,36], five $[15,18,20,26,27,31]$, or six hours $[14,17,19,26,31,38]$; only eight studies measured it continuously over one and a half [28], three [33], three and a half [16], four [25], five [15,37,39], or six [21] hours. Therefore, the duration of the DIT measurement period ranged from one and a half to six hours. The majority of studies measured DIT for five $[15,18,20,26,27,31,37,39]$ or six hours $[14,17,19,21,26,32,38]$. Mean DIT ranged from 4.5 to $99.4 \mathrm{~kJ} / \mathrm{h}$ and from 0.77 to $4.3 \% / \mathrm{h}(\mathrm{ECM})$, or from $1.3 \%$ to $41 \%$ above baseline (AB). 


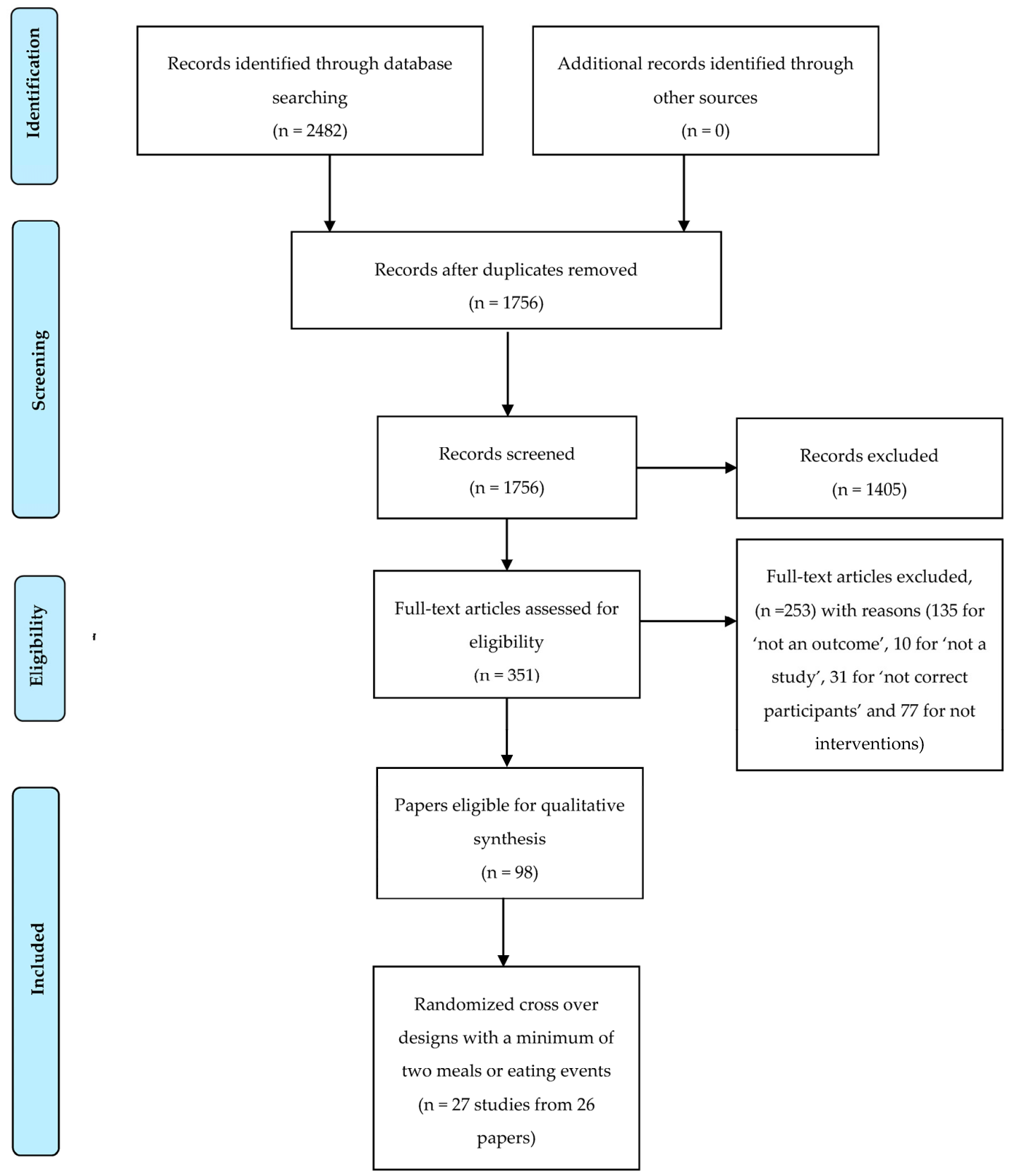

Figure 1. PRISMA Flow diagram [40] systematic search and review process. 
Table 1. Participant characteristics and study protocols.

\begin{tabular}{|c|c|c|c|c|c|}
\hline $\begin{array}{l}\text { Reference and } \\
\text { Location }\end{array}$ & $\begin{array}{l}\text { Sample }(n) \\
\text { Males }(m) \% \\
\text { Age (Years) }\end{array}$ & $\begin{array}{l}\text { BMI }\left(\mathrm{kg} / \mathrm{m}^{2}\right) \\
\text { FFM }(\% \text { or } \mathrm{kg}) \\
\text { FM }(\% \text { or } \mathrm{kg})\end{array}$ & $\begin{array}{l}\text { RMR (kJ/h, Measured before } \\
\text { Interventions a, b, c, etc.) }\end{array}$ & Protocol & $\begin{array}{c}\text { Gap between Intervention Meals and } \\
\text { Types of Meals Provided }\end{array}$ \\
\hline \multicolumn{6}{|c|}{ Higher vs. lower energy intake } \\
\hline $\begin{array}{l}\text { Kinabo and } \\
\text { Durnin [31]-Paper A } \\
\text { UK }\end{array}$ & $\begin{array}{l}n=16 \\
m=0^{+} \% \\
22(5.8)^{\dagger} \text { years }\end{array}$ & $\begin{array}{l}\mathrm{BMI}=20.8(0.2)^{\dagger} \\
\mathrm{FFM}=42.9(3.1)^{\dagger} \mathrm{kg} \\
\mathrm{FM}=240(23.2)^{\dagger} \mathrm{g} / \mathrm{kg} \\
\text { body weight }\end{array}$ & $\begin{array}{l}\text { (a) } 2222^{+}(69.7)^{\dagger} \\
\text { (b) } 219^{+}(69.7)^{\dagger} \\
\text { (c) } 221.4^{\dagger}(69.7)^{\dagger} \\
\text { (d) } 208.2^{\dagger}(69.7)^{\dagger}\end{array}$ & $\begin{array}{l}\text { Arrival at } 8: 00 \text { a.m.; fasting from } \\
\text { 8:00 p.m. } 30 \text { min rest; RMR } \\
\text { measured, meal consumed within } \\
10 \text { min. }\end{array}$ & $\begin{array}{l}\text { Gap = each meal provided on } \\
\text { different days. } \\
\text { (a) high CHO, low Fat-lower energy } \\
\text { (b) low CHO, high Fat-lower energy } \\
\text { (c) high CHO, low Fat-higher energy } \\
\text { (d) low CHO, high Fat--higher energy }\end{array}$ \\
\hline $\begin{array}{l}\text { Hill et al. [23] } \\
\text { USA }\end{array}$ & $\begin{array}{l}n=8\left(4 \text { low } \mathrm{VO}_{2} \max \text { group }\right. \\
\text { average is } 43 \mathrm{~mL} / \mathrm{kg} / \mathrm{min}-4 \\
\text { high } \mathrm{VO}_{2} \mathrm{max} \text { group average } \\
\text { is } 62 \mathrm{~mL} / \mathrm{kg} / \mathrm{min}) \\
m=100^{+} \% \\
\text { high } \mathrm{VO}_{2} \text { max } 20(3.5)^{+} \text {years } \\
\text { low } \mathrm{VO}_{2} \max 26(5.2)^{+} \text {years }\end{array}$ & $\begin{array}{l}\text { High } \mathrm{VO}_{2} \max \\
\mathrm{BMI}=21.9^{+} \\
\mathrm{FFM}=62.9^{+}(3.6)^{\dagger} \mathrm{kg} \\
\mathrm{FM}=13.8(2.8)^{+} \% \\
\text { Low } \mathrm{VO}_{2} \max \\
\mathrm{BMI}=23.7^{+} \\
\mathrm{FFM}=66.8(6.9)^{\dagger} \mathrm{kg} \\
\mathrm{FM}=16(4.2)^{+} \%\end{array}$ & $\begin{array}{l}\mathrm{High} \mathrm{VO}_{2} \text { max subjects } 301.7^{\dagger} \\
(22.5)^{+} \\
\text {Low } \mathrm{VO}_{2} \text { max subjects } 294.6^{+} \\
(40.5)^{+}\end{array}$ & $\begin{array}{l}12 \mathrm{~h} \text { fast; rest for } 60-90 \mathrm{~min} \text {; then } \\
\text { RMR measured; meals consumed } \\
\text { within } 10 \mathrm{~min} \text {. }\end{array}$ & $\begin{array}{l}\text { Gap = NPI } \\
\text { Liquid meal (a) lower energy intake } \\
\text { (b) medium level energy intake } \\
\text { (c) higher energy intake }\end{array}$ \\
\hline $\begin{array}{l}\text { Martin et al. [36] } \\
\quad \text { France }\end{array}$ & $\begin{array}{l}n=10 \\
m=100+\% \\
28(2) \text { years }\end{array}$ & $\mathrm{BMI}=22.2(0.5)$ & & $\begin{array}{l}14 \text { days of intervention meals: } \\
\text { meal consumed at research centre } \\
\text { daily between 7:00 and 8:00 a.m. } \\
\text { On day 15: arrive at 7:00 a.m.; } \\
\text { overnight fast; RMR measured; } \\
\text { meal consumed within } 30 \text { min at } \\
\text { 8:00 a.m. }\end{array}$ & $\begin{array}{l}\text { Gap }=28 \text { days } \\
\text { (a) } 14 \text { days of intervention meals: low } \\
\text { energy, moderate fat breakfast } \\
\text { (b) } 14 \text { days of intervention meals: high } \\
\text { energy, low fat breakfast }\end{array}$ \\
\hline $\begin{array}{l}\text { Bennet et al. [21] } \\
\text { USA }\end{array}$ & $\begin{array}{l}n=4 \text { (untrained) } \\
m=100^{+} \% \\
28(8) \text { years } \\
\text { Excluded trained subjects }\end{array}$ & $\begin{array}{l}\mathrm{BMI}=23^{\dagger}(3)^{+} \\
\mathrm{FM}=20.5^{+}(4.3)^{\dagger} \%\end{array}$ & & Meal consumed at 8:30 a.m. & $\begin{array}{l}\text { Gap } \geq 24 \mathrm{~h} \\
\text { (a) normal meal provided ( } 25 \% \text { of } \\
\text { energy intake of the total day) } \\
\text { (b) high fat meal: plus } 50 \mathrm{~g} \text { of fat } \\
\text { compared to the normal fat meal }\end{array}$ \\
\hline $\begin{array}{l}\text { Segal et al. [22] } \\
\text { USA }\end{array}$ & $\begin{array}{l}n=11 \\
m=100+\% \\
31(6.3)^{\dagger} \text { years } \\
\text { Excluded obese subjects }\end{array}$ & $\begin{array}{l}\mathrm{BMI}=25.5^{\dagger} \\
\mathrm{FFM}=66.1(4.1)^{\dagger} \mathrm{kg} \\
\mathrm{FM}=15.3(2.2)^{\dagger} \%\end{array}$ & $343.9^{\dagger}(31.6)^{+}$ & $\begin{array}{l}12 \mathrm{~h} \text { fast; } 9: 00 \mathrm{a} \text { a.m. arrival; } \\
30 \text { min rest; RMR measured for } \\
\text { three five-minute measurements. }\end{array}$ & $\begin{array}{l}\text { Gap }=\text { NPI } \\
\text { (a) } 35 \% \text { of each man } 24 \text { h RMR meal } \\
\text { (b) } 3013 \mathrm{~kJ} \text { meal }\end{array}$ \\
\hline \multicolumn{6}{|c|}{ Meals varying in macronutrients composition } \\
\hline $\begin{array}{l}\text { Nagai et al. [30] } \\
\text { Japan }\end{array}$ & $\begin{array}{l}n=14 \\
m=100+\% \\
23.6(1.8)^{\dagger} \text { years }\end{array}$ & $\begin{array}{l}\mathrm{BMI}=21.3(1.4)^{\dagger} \\
\mathrm{FM}=18.4(3.6)^{+} \%\end{array}$ & $\begin{array}{l}375.3^{+}(39.7)^{+} \\
373.2^{+}(44.0)^{+}\end{array}$ & $\begin{array}{l}\text { Fast from } 10: 00 \text { p.m.; arrival at } \\
\text { 7:30 a.m.; rest for } 30 \text { min; } \\
\text { continuous RMR measurement. } \\
\text { (NP length); meals consumed at } \\
\text { 8:30 a.m. within } 15 \text { min. }\end{array}$ & $\begin{array}{l}\text { Gap = NPI } \\
\text { (a) standard meal—low fat meal } \\
\text { (b) standard meal-high fat meal }\end{array}$ \\
\hline
\end{tabular}


Table 1. Cont

\begin{tabular}{|c|c|c|c|c|c|}
\hline $\begin{array}{l}\text { Reference and } \\
\text { Location }\end{array}$ & $\begin{array}{l}\text { Sample }(n) \\
\text { Males }(m) \% \\
\text { Age (Years) }\end{array}$ & $\begin{array}{l}\text { BMI }\left(\mathrm{kg} / \mathrm{m}^{2}\right) \\
\text { FFM (\% or } \mathrm{kg}) \\
\text { FM }(\% \text { or } \mathrm{kg})\end{array}$ & $\begin{array}{l}\text { RMR (kJ/h, Measured before } \\
\text { Interventions } a, b, c \text {, etc.) }\end{array}$ & Protocol & $\begin{array}{c}\text { Gap between Intervention Meals and } \\
\text { Types of Meals Provided }\end{array}$ \\
\hline \multicolumn{6}{|c|}{ Meals varying in macronutrients composition } \\
\hline $\begin{array}{l}\text { Blundell, Cooling and } \\
\text { King [33] } \\
\text { UK }\end{array}$ & $\begin{array}{l}n=24 \\
m=100^{\dagger} \% \\
\text { High fat consumers }(n=12) \\
20.7(1.6)^{\dagger} \text { years } \\
\text { Low fat consumers }(n=12) \\
21.6(2.3)^{\dagger} \text { years }\end{array}$ & $\begin{array}{l}\text { High fat consumers } \\
\text { BMI }=21.2(5 .)^{\dagger} \\
\mathrm{FM}=11.1(4.3)^{+} \% \\
\text { Low fat consumers BMI }= \\
22.4(2.0)^{+} \\
\mathrm{FM}=11.4(4.3)^{+}\end{array}$ & $\begin{array}{l}\text { High fat consumers } 286.08^{+} \\
(0.02)^{+} \\
\text {Low fat consumers } 259.58^{+} \\
(0.03)^{+}\end{array}$ & $\begin{array}{l}\text { Arrival at } ~ 9: 00 \text { a.m. after } 12 \mathrm{~h} \\
\text { fast; } 30 \text { min of steady RMR were } \\
\text { measured; milkshake consumed } \\
\text { within } 5 \text { min. }\end{array}$ & $\begin{array}{l}\text { Gap = NPI } \\
\text { (a) high fat milkshakes drink } \\
\text { (b) high CHO milkshake drink }\end{array}$ \\
\hline $\begin{array}{c}\text { Bowden and McMurray } \\
{[20]} \\
\text { USA }\end{array}$ & $\begin{array}{l}n=6 \\
m=0^{+} \% \\
33.8(10.7) \text { years } \\
\text { Excluded trained subjects }\end{array}$ & $\begin{array}{l}\mathrm{BMI}=21.7(1.6) \\
\mathrm{FFM}=43.9(3.3) \mathrm{Kg} \\
\mathrm{FM}=21.4(3.7) \%\end{array}$ & $208.2^{\dagger}(12.6)^{\dagger}$ & $\begin{array}{l}\text { Arrival at lab at } 6: 30 \text { a.m.; } 10 \mathrm{~h} \\
\text { fast; RMR obtained over two } \\
5 \text { min periods; meal consumed } \\
\text { within } 20 \text { min }\end{array}$ & $\begin{array}{l}\text { Gap }=2 \text { days } \\
\text { (a) high CHO meal } \\
\text { (b) high fat meal }\end{array}$ \\
\hline $\begin{array}{l}\text { Thyfault et al. [25] } \\
\text { USA }\end{array}$ & $\begin{array}{l}n=12 \text { Sedentary } \\
m=100^{+} \% \\
24.8(4.6)^{+} \text {years } \\
\text { Excluded trained subjects }\end{array}$ & $\begin{array}{l}\mathrm{FM}=21.5(4.3)^{\dagger} \% \\
\mathrm{FFM}=58.3(2.7)^{\dagger} \mathrm{kg}\end{array}$ & $7262(394.7) \mathrm{kJ}^{\dagger}-\mathrm{NP}$ unit of time & $\begin{array}{l}\text { Arrival at 5:00 a.m.; } 12 \mathrm{~h} \text { fast; } \\
30 \text { min supine rest; RMR } \\
\text { measured for } 30 \mathrm{~min} ; \text { meal } \\
\text { consumed within } 10 \text { min. }\end{array}$ & $\begin{array}{l}\text { Gap }=7 \text { days } \\
\text { (a) high carbohydrate liquid meal } \\
\text { (b) moderate fat liquid meal }\end{array}$ \\
\hline $\begin{array}{l}\text { Raben et al. [15] } \\
\text { Denmark }\end{array}$ & $\begin{array}{l}n=19 \\
m=52.6^{+} \% \\
23.3(2.1)^{+} \text {years }\end{array}$ & $\begin{array}{l}\mathrm{BMI}=22.1(1.7)^{\dagger} \\
\mathrm{FM}=18.8(4.7)^{+} \%\end{array}$ & & $\begin{array}{l}\text { Arrival at } 8: 00 \text { a.m.; } 10 \mathrm{~h} \text { fast; } \\
30 \text { min supine rest; RMR } \\
\text { measured for } 45 \mathrm{~min} \text {; meals } \\
\text { consumed within } 15 \text { min at } \\
\text { 9:45 a.m. }\end{array}$ & $\begin{array}{l}\text { Gap }=\geq 4 \text { weeks and no more than } \\
8 \text { weeks } \\
\text { standard meal } \\
\text { (a) high protein meal } \\
\text { (b) high fat meal } \\
\text { (c) high CHO meal } \\
\text { Excluded high alcohol meal }\end{array}$ \\
\hline $\begin{array}{l}\text { Petzke and Klaus [38] } \\
\text { Germany }\end{array}$ & $\begin{array}{l}n=6 \\
m=0+\% \\
25.5(2.6) \text { years }\end{array}$ & $\mathrm{BMI}=20.6(2.5)$ & $\begin{array}{l}\text { (a) } 218(12) \\
\text { (b) } 230(13)\end{array}$ & $\begin{array}{l}12 \mathrm{~h} \text { fast; RMR measured for } \\
30 \text { min between } 8 \text { and } 9 \text { a.m.; } \\
\text { meal ingested between } 9 \text { and } \\
\text { 9:30 a.m. and within } 10 \text { min. }\end{array}$ & $\begin{array}{l}\text { Gap }=2 \text { days } \\
\text { (a) low protein meal } \\
\text { (b) adequate protein meal }\end{array}$ \\
\hline $\begin{array}{l}\text { Riggs et al. [24] } \\
\text { USA }\end{array}$ & $\begin{array}{l}n=21 \\
m=0^{+} \% \\
\text { Overweight }(n=6) \\
22.8(2.4)^{+} \text {years } \\
\text { Normal weight }(n=12) \\
20.8(2.6)^{+} \\
\text {Underweight }(n=3) \\
20.7(2.2)^{+} \text {years }\end{array}$ & $\begin{array}{l}\text { Overweight } \\
\text { BMI }=26.9(1.7)^{\dagger} \\
\text { FFM }=48.4(3.9)^{\dagger} \mathrm{kg} \\
\mathrm{FM}=31.4(2.7)^{\dagger} \% \\
\text { Normal weight } \\
\text { BMI }=21.1(1.7)^{+} \\
\text {FFM }=44.6(4.0)^{\dagger} \mathrm{kg} \\
\mathrm{FM}=23.0(2.9)^{\dagger} \% \\
\text { Underweight } \\
\text { BMI }=18.1(1.5)^{+} \\
\mathrm{FFM}=41.7(4.0)^{+} \mathrm{kg} \\
\mathrm{FM}=19.5(2.4)^{\dagger} \%\end{array}$ & & $\begin{array}{l}12 \mathrm{~h} \text { fast; } 10 \text { min rest; RMR } \\
\text { measured between } 7 \text { and 8:00 } \\
\text { a.m.; meal eaten within } \\
15-20 \text { min. }\end{array}$ & $\begin{array}{l}\text { Gap }=1 \text { week to } 2.5 \text { months } \\
\text { (a) high protein, high fat bars } \\
\text { (b) high protein, low fat bars }\end{array}$ \\
\hline $\begin{array}{l}\text { Clegg et al. [17] } \\
\text { UK }\end{array}$ & $\begin{array}{l}n=7 \\
m=14.3+\% \\
25.7(3.6) \text { years }\end{array}$ & $\mathrm{BMI}=21.9^{\dagger}$ & & $\begin{array}{l}\text { Arrived after an overnight fast; } \\
\text { rested for } 30 \mathrm{~min} \text {; RMR measured } \\
\text { between 7:30 a.m. to 9:00 a.m. at } \\
1 \text { min intervals for } 30 \mathrm{~min} ; \text { meal } \\
\text { consumed within } 15 \mathrm{~min} .\end{array}$ & $\begin{array}{l}\text { Gap = minimum of four days } \\
\text { (a) meal with bell pepper and } \\
\text { sunflower oil (18.4 g) } \\
\text { (b) meal with bell pepper and MCT oil } \\
(20.0 \mathrm{~g}) \\
\text { Excluded two chilli meals }\end{array}$ \\
\hline
\end{tabular}


Table 1. Cont.

\begin{tabular}{|c|c|c|c|c|c|}
\hline $\begin{array}{l}\text { Reference and } \\
\text { Location }\end{array}$ & $\begin{array}{l}\text { Sample }(n) \\
\text { Males }(m) \% \\
\text { Age (Years) }\end{array}$ & $\begin{array}{c}\text { BMI }\left(\mathrm{kg} / \mathrm{m}^{2}\right) \\
\text { FFM }(\% \text { or } \mathrm{kg}) \\
\text { FM }(\% \text { or } \mathrm{kg})\end{array}$ & $\begin{array}{l}\text { RMR (kJ/h, Measured before } \\
\text { Interventions } a, b, c \text {, etc.) }\end{array}$ & Protocol & $\begin{array}{c}\text { Gap between Intervention Meals and } \\
\text { Types of Meals Provided }\end{array}$ \\
\hline \multicolumn{6}{|c|}{ Meals varying in macronutrients composition } \\
\hline $\begin{array}{c}\text { Kasai et al._-study } 1 \\
{[14]} \\
\text { Japan }\end{array}$ & $\begin{array}{l}n=8 \\
m=100+\% \\
26.8(1.9)^{\dagger} \text { years }\end{array}$ & $\mathrm{BMI}=22.7(2.1)^{\dagger}$ & $\begin{array}{l}\text { (a) } 294.6^{\dagger}(32.3)^{\dagger} \\
\text { (b) } 280.3^{+}(29.9)^{\dagger} \\
\text { (c) } 286.3^{\dagger}(23.5)^{\dagger}\end{array}$ & $\begin{array}{l}\text { Dinner at 9:00 p.m.; overnight } \\
\text { fast; meal consumed at 11:00 a.m. }\end{array}$ & $\begin{array}{l}\text { Gap = NP } \\
\text { Liquid meal with (a) } 10 \mathrm{~g} \mathrm{LCT} \\
\text { (b) } 5 \mathrm{~g} \mathrm{MCT} \text {; } 5 \mathrm{gCT} \\
\text { (c) } 10 \mathrm{~g} \mathrm{MCT}\end{array}$ \\
\hline $\begin{array}{c}\text { Kasai et al._-study } 2 \\
{[14]} \\
\text { Japan }\end{array}$ & $\begin{array}{l}n=8(n=7 \text { for the two } \\
\text { mayonnaise arms as one drop } \\
\text { out) } \\
m=0^{+} \% \\
28.1(3.7)^{+} \text {years }\end{array}$ & $\mathrm{BMI}=18.8(1.1)^{\dagger}$ & $\begin{array}{l}\text { (a) } 211.1^{\dagger}(14.9)^{\dagger} \\
\text { (b) } 206.2^{\dagger}(22.5)^{\dagger} \\
\text { (c) } 209.4^{\dagger}(34.9)^{\dagger} \\
\text { (d) } 198.2^{\dagger}(32.8)^{\dagger}\end{array}$ & $\begin{array}{l}\text { Dinner at 9:00 p.m.; overnight } \\
\text { fast; meal consumed at 11:00 a.m. }\end{array}$ & $\begin{array}{l}\text { Gap }=1 \text { to } 2 \text { day interval within the } \\
\text { same week for each experimental } \\
\text { session (mayonnaise trials and } \\
\text { margarine trials) } \\
\text { Standard meal with (a) mayonnaise } \\
\text { with } 5 \mathrm{~g} \mathrm{LCT} \\
\text { (b) mayonnaise with } 5 \mathrm{~g} \mathrm{MCT} \\
\text { (c) margarine with } 5 \mathrm{~g} \mathrm{LCT} \\
\text { (d) margarine with } 5 \mathrm{~g} \mathrm{MCT}\end{array}$ \\
\hline $\begin{array}{c}\text { Casas-Agustench et al. } \\
{[39]} \\
\text { Spain }\end{array}$ & $\begin{array}{l}n=29 \\
m=100+\% \\
22(4) \text { years }\end{array}$ & $\mathrm{BMI}=24.1(4.5)$ & $\begin{array}{l}\text { (a) } 318.5(95 \% \text { CI 298.2-338.8) } \\
\text { (b) } 318.9(95 \% \text { CI 298.5-339.3) } \\
\text { (c) } 323.2(95 \% \text { CI 302.3-344.1) }\end{array}$ & $\begin{array}{l}\text { Arrived at } 8: 00 \text { a.m. fast; } 10 \mathrm{~min} \\
\text { rest; RMR measured for } 30 \mathrm{~min} ; \\
\text { meal provided at 9:00 a.m. and } \\
\text { eaten within } 30 \mathrm{~min}\end{array}$ & $\begin{array}{l}\text { Gap = 1-11 days } \\
\text { (a) standard meal rich in PUFA } \\
\text { (b) standard meal rich in MUFA } \\
\text { (c) standard meal rich in SFA }\end{array}$ \\
\hline $\begin{array}{l}\text { Piers et al. [18] } \\
\quad \text { Australia }\end{array}$ & $\begin{array}{l}n=14 \\
m=100+\% \\
38(9) \text { years }\end{array}$ & $\begin{array}{l}\mathrm{BMI}=27.8(3.2) \\
\mathrm{FFM}=62.7(8.5) \mathrm{kg} \\
\mathrm{FM}=29.5(4.8) \%\end{array}$ & $\begin{array}{l}\text { (a) } 311(40) \\
\text { (b) } 307(36)\end{array}$ & $\begin{array}{l}\text { Arrival at 7:00-8:00 a.m.; } 12-14 \mathrm{~h} \\
\text { of fast; } 30 \mathrm{~min} \text { rest; RMR } \\
\text { measured for } 35 \mathrm{~min} .\end{array}$ & $\begin{array}{l}\text { Gap }=7-14 \text { days } \\
\text { (a) meal with SFA } \\
\text { (b) meal with MUFA }\end{array}$ \\
\hline $\begin{array}{l}\text { Bendixen et al. [37] } \\
\text { Denmark }\end{array}$ & $\begin{array}{l}n=11 \\
m=100+\% \\
25.1(1.6)^{\dagger} \text { years }\end{array}$ & $\begin{array}{l}\mathrm{BMI}=22.5(1.9)^{+} \\
\mathrm{FM}=18(3.2)^{+} \% \\
\mathrm{FFM}=62.9(6.3)^{+} \mathrm{kg}\end{array}$ & $\begin{array}{l}\text { (a) } 290.4^{\dagger}(28.5)^{\dagger} \\
\text { (b) } 289.8^{\dagger}(22.8)^{\dagger} \\
\text { (c) } 292.2^{\dagger}(26.6)^{\dagger} \\
\text { (d) } 289.8^{\dagger}(34.2)^{\dagger}\end{array}$ & $\begin{array}{l}\text { Fast } \geq 12 \mathrm{~h} ; 30 \mathrm{~min} \text { supine rest; } \\
\text { RMR measured for } 45 \mathrm{~min} ; \\
\text { meal consumed by } 15 \mathrm{~min} .\end{array}$ & $\begin{array}{l}\text { Gap = 14-28 days } \\
\text { Standard meal with liquid test drink } \\
\text { (a) conventional fat (rapeseed oil) } \\
\text { (b) chemically structured fat (rapeseed } \\
\text { oil and octanoic acid by esterification } \\
\text { with sodium methoxide) } \\
\text { (c) lipase structured fat (rapeseed oil } \\
\text { and octanoic acid by esterification with } \\
\text { lipoxime IM) } \\
\text { (d) physically mixed fat (blending } \\
\text { rapessed oil and trioctanoate) }\end{array}$ \\
\hline \multicolumn{6}{|c|}{ Processed vs. unprocessed meals } \\
\hline $\begin{array}{l}\text { Barr and Wright [26] } \\
\text { USA }\end{array}$ & $\begin{array}{l}n=17 \text { in analyses } \\
m=29.4^{+} \% \\
25.5(12.4)^{+} \text {years }\end{array}$ & $\mathrm{BMI}=22.0(2.2)^{\dagger}$ & & $\begin{array}{l}\text { Fast for } 12 \mathrm{~h} ; 2 \text { RMR } \\
\text { measurements } \sim 30 \text { min apart } \\
\text { before and just before consuming } \\
\text { the meal; meals consumed } \\
\text { between } 9: 15 \text { and } 11: 15 \text { a.m. and } \\
\text { at approximately the same time } \\
\text { for each measurement sessions. }\end{array}$ & $\begin{array}{l}\text { Gap }=\text { on two consecutive days or not } \\
\text { longer than a week apart. } \\
\text { (a) whole-food meal as either } 1 \frac{1}{2} \\
\text { sandwich or } 2 \text { sandwiches } \\
\text { (b) pre-prepared processed foods as } \\
\text { either } 1 \frac{1}{2} \text { sandwich or } 2 \text { sandwiches. }\end{array}$ \\
\hline
\end{tabular}


Table 1. Cont

\begin{tabular}{|c|c|c|c|c|c|}
\hline $\begin{array}{l}\text { Reference and } \\
\text { Location }\end{array}$ & $\begin{array}{l}\text { Sample }(n) \\
\text { Males }(m) \% \\
\text { Age (Years) }\end{array}$ & $\begin{array}{l}\text { BMI }\left(\mathrm{kg} / \mathrm{m}^{2}\right) \\
\text { FFM }(\% \text { or } \mathrm{kg}) \\
\text { FM }(\% \text { or } \mathrm{kg})\end{array}$ & $\begin{array}{l}\text { RMR (kJ/h, Measured before } \\
\text { Interventions } \mathrm{a}, \mathrm{b}, \mathrm{c} \text {, etc.) }\end{array}$ & Protocol & $\begin{array}{c}\text { Gap between Intervention Meals and } \\
\text { Types of Meals Provided }\end{array}$ \\
\hline \multicolumn{6}{|c|}{ Bolus vs. smaller frequent meals } \\
\hline $\begin{array}{l}\text { Kinabo and Durnin } \\
\text { [32]-Paper B } \\
\text { Scotland, UK }\end{array}$ & $\begin{array}{l}n=18 \\
m=0^{+} \% \\
\text { Group A }(n=8) \\
24(5.3)^{+} \text {years } \\
\text { Group B }(n=10) \\
20(7.2)^{+} \text {years }\end{array}$ & $\begin{array}{l}\text { Group A } \\
\text { BMI }=21(1.3)^{\dagger} \\
\text { FFM }=42.4(2.9)^{\dagger} \mathrm{kg} \\
\text { FM }=23(2.6)^{\dagger} \% \\
\text { Group B } \\
\text { BMI }=21(2.1) \\
\text { FFM }=43.6(4.2)^{\dagger} \mathrm{kg} \\
\text { FM }=23(6)^{+} \%\end{array}$ & $\begin{array}{l}\text { Group A: } \\
\text { (a) } 226.8^{\dagger}(27.0)^{\dagger} \\
\text { (b) } 214.8^{\dagger}(20.6)^{+} \\
\text {Group B } \\
\text { (c) } 230.4^{+}(30.6)^{+} \\
\text {(d) } 221.4^{\dagger}(14.4)^{\dagger}\end{array}$ & $\begin{array}{l}\text { Arrival at } 8: 00 \text { a.m., at least } 12 \mathrm{~h} \\
\text { fast; } 30 \text { min supine rest; RMR } \\
\text { measured; meal consumed either } \\
\text { as a large bolus meal within } \\
20 \text { min or as two smaller meals } \\
\text { within } 10 \text { min every } 180 \text { min. }\end{array}$ & $\begin{array}{l}\text { Gap = } 1 \text { week } \\
\text { Group A: } \\
\text { (a) high carb-low fat meal; } \\
\text { one large meal } \\
\text { (b) high carb-low fat meal; } \\
\text { two smaller meals } \\
\text { Group B: } \\
\text { (c) low carb-high fat meal; } \\
\text { one large meal } \\
\text { (d) low carb-high fat meal; } \\
\text { two smaller meals }\end{array}$ \\
\hline $\begin{array}{l}\text { Vaz et al. [34] } \\
\text { Australia }\end{array}$ & $\begin{array}{l}n=10 \\
m=100+\%\end{array}$ & $\begin{array}{l}\text { BMI }=22.9(1.8)^{\dagger} \\
\mathrm{FFM}=64(5.7)^{+} \mathrm{kg} \\
\mathrm{FM}=16.6(6.0)^{+} \%\end{array}$ & & $\begin{array}{l}\text { 12-14 h overnight fast; RMR } \\
\text { measured after } 30 \text { min rest. }\end{array}$ & $\begin{array}{l}\text { Gap = approximately } 14 \text { days } \\
\text { (a) standard meal-single meal } \\
\text { (b) standard meal- three smaller meals }\end{array}$ \\
\hline $\begin{array}{l}\text { Allirot et al. [35] } \\
\text { France }\end{array}$ & $\begin{array}{l}n=20 \\
m=100+\% \\
27.1(5.7)^{+} \text {years }\end{array}$ & $\mathrm{BMI}=22.0(1.3)^{\dagger}$ & & $\begin{array}{l}\text { Arrival at 7:00 a.m.; fast since } \\
\text { 9:00 p.m.; RMR measured for } \\
30 \text { min; meals consumed either as } \\
\text { a bolus event within } 20 \text { min or as } \\
\text { smaller meals every hour within } \\
10 \text { min each. }\end{array}$ & $\begin{array}{l}\text { Gap }=\text { at least } 7 \text { days } \\
\text { (a) one } 20 \text { min long episode } \\
\text { (b) } 4 \text { smaller meals in } 10 \text { min episodes }\end{array}$ \\
\hline $\begin{array}{l}\text { Tai et al. [27] } \\
\text { USA }\end{array}$ & $\begin{array}{l}n=7 \\
m=0+\% \\
26.7(2.9) \text { years }\end{array}$ & $\begin{array}{l}\mathrm{BMI}=20.8(2.1) \\
\mathrm{FM}=17.1(5.4) \%\end{array}$ & $\begin{array}{l}\text { (a) } 233.7^{\dagger}(9.8)^{\dagger} \\
\text { (b) } 236.22^{\dagger}(14.1)^{\dagger}\end{array}$ & $\begin{array}{l}\text { RMR measured after } 12-14 \mathrm{~h} \text { fast } \\
\text { and minimum of } 30 \text { min rest; } \\
\text { meals consumed as one bolus } \\
\text { event within } 10 \mathrm{~min} \text { or as smaller } \\
\text { meals every } 30 \mathrm{~min} \text {. }\end{array}$ & $\begin{array}{l}\text { Gap = meals provided on } \\
\text { different days } \\
\text { (a) liquid meal taken in one eating } \\
\text { event of } 10 \text { min long } \\
\text { (b) liquid meal in } 6 \text { equal smaller meals } \\
\text { at } 30 \text { min interval over } 150 \text { min. }\end{array}$ \\
\hline \multicolumn{6}{|c|}{ Fast vs. slow eating patterns } \\
\hline $\begin{array}{l}\text { Hamada et al. [28] } \\
\text { Japan }\end{array}$ & $\begin{array}{l}n=10 \\
m=100+\% \\
25(1) \text { years }\end{array}$ & $\begin{array}{l}\mathrm{BMI}=19.8^{\dagger} \\
\mathrm{FM}=13(2) \%\end{array}$ & & $\begin{array}{l}\text { Fast since dinner }(>10 \mathrm{~h}) ; 20 \mathrm{~min} \\
\text { semi-supine position rest; RMR } \\
\text { measured for } 20 \mathrm{~min} .\end{array}$ & $\begin{array}{l}\text { Gap }=\text { NPI } \\
\text { standard meal } \\
\text { (a) rapid eating } \\
\text { (b) slow eating }\end{array}$ \\
\hline $\begin{array}{l}\text { Toyama et al. [29] } \\
\text { Japan }\end{array}$ & $\begin{array}{l}n=9 \\
m=0 \% \\
22(2.1) \text { years }\end{array}$ & $\begin{array}{l}\text { BMI } \\
\text { (a) } 21.3(1.7) \\
\text { (b) } 21.3(1.8) \\
\text { FM } \\
\text { (a) } 24.1(3.8) \% \\
\text { (b) } 24.0(4.0) \%\end{array}$ & $\begin{array}{l}\text { (a) } 196.8^{\dagger}(17.3)^{\dagger} \\
\text { (b) } 191.6^{\dagger}(17.6)^{\dagger}\end{array}$ & $\begin{array}{l}\text { Dinner by 9:00 p.m., fast until } \\
\text { morning; arrival at 8:00 a.m., } 30 \\
\text { min supine rest; RMR measured; } \\
\text { meal consumed at 9:00 a.m. }\end{array}$ & $\begin{array}{l}\text { Gap }=\text { at least } 7 \text { days } \\
\text { Same meal provided } \\
\text { (a) fast eating }(5 \mathrm{~min}) \\
\text { (b) regular eating }(15 \mathrm{~min})\end{array}$ \\
\hline
\end{tabular}


Table 1. Cont.

\begin{tabular}{|c|c|c|c|c|c|}
\hline $\begin{array}{l}\text { Reference and } \\
\text { Location }\end{array}$ & $\begin{array}{l}\text { Sample }(n) \\
\text { Males }(m) \% \\
\text { Age (Years) }\end{array}$ & $\begin{array}{c}\text { BMI }\left(\mathrm{kg} / \mathrm{m}^{2}\right) \\
\text { FFM }(\% \text { or } \mathrm{kg}) \\
\text { FM (\% or } \mathrm{kg})\end{array}$ & $\begin{array}{l}\mathrm{RMR}(\mathrm{kJ} / \mathrm{h} \text {, Measured before } \\
\text { Interventions } \mathrm{a}, \mathrm{b}, \mathrm{c} \text {, etc.) }\end{array}$ & Protocol & $\begin{array}{c}\text { Gap between Intervention Meals and } \\
\text { Types of Meals Provided }\end{array}$ \\
\hline \multicolumn{6}{|c|}{ Palatable vs. unpalatable meals } \\
\hline $\begin{array}{l}\text { Sawaya et al. [19] } \\
\text { USA }\end{array}$ & $\begin{array}{l}n=19 \\
m=100+\% \\
\text { Old }(n=9) \\
69.4(1.3) \text { years } \\
\text { Young }(n=10) \\
23.4(1) \text { years }\end{array}$ & $\begin{array}{l}\text { Old } \\
\text { BMI }=24.4(0.9) \\
\text { FFM }=55(2.2) \\
\text { FM }=26.2(1.9) \% \\
\text { Young } \\
\text { BMI }=22.7(0.5) \\
\text { FFM }=64.1(1.9) \mathrm{kg} \\
\text { FM }=12(1.3) \%\end{array}$ & 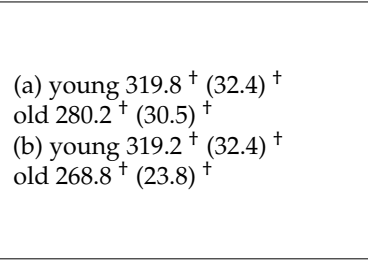 & $\begin{array}{l}\text { Sleep at university by 10:00 p.m., } \\
\text { awakened at 6:30 a.m.; } 30 \mathrm{~min} \\
\text { rest; RMR measured for } 30 \mathrm{~min} \text {; } \\
\text { meals consumed within } 20 \mathrm{~min} \text {. }\end{array}$ & $\begin{array}{l}\text { Gap }=1 \text { week interval } \\
\text { (a) palatable meal } \\
\text { (b) control meal }\end{array}$ \\
\hline $\begin{array}{l}\text { Weststrate et al. [16] } \\
\text { Netherlands—study } 1\end{array}$ & $\begin{array}{l}n=12 \\
m=50^{+} \% \\
\text { Men } 22.7(1.8)^{\dagger} \text { years } \\
\text { Women } \\
21.2(1.8)^{\dagger} \text { years }\end{array}$ & $\begin{array}{l}\text { Men } \\
\text { FM }=12.0(2.2)+\% \\
\text { Women } \\
\text { FM }=29.0(2.5)+\%\end{array}$ & & Overnight fast. & $\begin{array}{l}\text { Gap }=\text { At least } 2 \text { days } \\
\text { (a) palatable meal } \\
\text { (b) unpalatable meal }\end{array}$ \\
\hline
\end{tabular}

Data are described in mean (SD) unless otherwise indicated. ${ }^{+}$These data (mean and/or SD) were calculated or converted for one or more of these possible calculations or conversions (calculated the average and/or SD from individuals' data; kcal converted to kJ; MJ converted to kJ; RMR kJ converted for unit of time; SE converted to SD, males' percentage calculated from the total number of males in the sample). "+ Kinabo et al. [31] - paper A is also part of results section: "meals varying in macronutrient composition". a, b, c or $\mathrm{d}$ : refers to the different types of interventions provided as explained in the last column (gap between intervention meals and types of meals provided). BMI = Body Mass Index. $\mathrm{CHO}=$ Carbohydrate. FM = Fat Mass. FFM = Fat Free Mass. $\mathrm{LCT}=$ Long Chain Triglycerides. $\mathrm{M}=$ Males. MCT $=$ Medium Chain Triglycerides. MUFA $=$ Mono Unsaturated Fatty Acids. $\mathrm{N}=$ Sample. NP = Not Provided. NPI = Not Provided Information. PUFA = Poly Unsaturated Fatty Acids. RMR = Resting Metabolic Rate. SFA = Saturated Fatty Acids.

$\mathrm{VO}_{2}=$ Rate of Oxygen consumption 


\subsection{Comparison and Meta-Regression of the Effects of Higher and Lower Energy Intakes on DIT}

Five studies $[21-23,31,36]$ with the primary aim of comparing the effects of meals with different energy intakes on DIT were identified. Three studies $[23,31,36]$ found an increased DIT when a higher energy intake was consumed, although only one indicated statistical significance [31]. Kinabo and Durbin [31] compared high CHO, low fat meals at two energy intake levels: $2520 \mathrm{~kJ}$ and $5040 \mathrm{~kJ}$, and low $\mathrm{CHO}$, high fat meals at the same two energy intake levels. This study found that a higher energy intake was associated with a significantly $(p<0.001)$ higher DIT, regardless of dietary composition. Higher energy intake $(5040 \mathrm{~kJ})$ resulted in a similar DIT for the high $\mathrm{CHO}$, low fat $(71.2(15.5) \mathrm{kJ} / \mathrm{h})$ and low $\mathrm{CHO}$, high fat $(68(12.4) \mathrm{kJ} / \mathrm{h}$ ) meals, and this was higher than the DIT for the lower energy intake (2520 kJ) high CHO, low fat (45.6 (9.3) kJ/h) and low CHO, high fat (45.6 (10.8) kJ/h) meals [31].

Hill et al. [23] compared DIT following three meals of $2092 \mathrm{~kJ}, 4184 \mathrm{~kJ}$, and $6276 \mathrm{~kJ}$ [23]. DIT was higher with higher energy intake: $2092 \mathrm{~kJ}$ meal DIT $<10 \%$ above baseline RMR; $4184 \mathrm{~kJ}$ meal DIT $21 \%$ above baseline RMR, and $6276 \mathrm{~kJ}$ meal DIT 33.5\% above baseline RMR, no $p$ value provided [23].

Martin et al. [36] compared two weeks of low energy, moderate fat meals (418 kJ) to two weeks of high energy, low fat meals (2929 kJ) and found a higher DIT after the high energy, low fat meals (low energy, moderate fat meals $4.5(1.4) \mathrm{kJ} / \mathrm{h}$; high energy, low fat meals $35.6(2.6) \mathrm{kJ} / \mathrm{h}$; no $p$ value provided [36]).

Bennet et al. [21] compared a high fat meal ( $\mathrm{kJ}$ not provided) to a normal fat meal (kJ not provided). The high fat meal was $1881 \mathrm{~kJ}$ higher due to the addition of $50 \mathrm{~g}$ of fat compared to the normal fat meal. This study did not find any significant differences in DIT (high fat meal $1.2(0.40) \% / \mathrm{h}$, normal fat meal $1.3(0.3) \% / \mathrm{h} ; p>0.05$ for $\% / 6 \mathrm{~h} \mathrm{ECM}$ for all participants, including some trained individuals, for the statistical tests) [21].

Segal et al. [22] compared consuming a meal with a fixed energy intake (3013 kJ) to a meal providing 35\% of each individual's $24 \mathrm{~h}$ RMR (caloric intake varying between participants, on average $2889 \mathrm{~kJ}$ intake) [22]. This study did not find any significant difference in DIT (fixed: 96.3 (17.6) kJ/h; 35\% RMR: 89.3 (17.6) $\mathrm{kJ} / \mathrm{h}, p>0.05$ for \%/3 h ECM) but there was little difference in the energy intakes between the two meals [22].

In order to further resolve the effect of energy intake on DIT, mixed model meta-regression analyses were undertaken to investigate more broadly the relationship between energy intake $(\mathrm{kJ})$ after an overnight fast and DIT (kJ/h). Two models were produced: the first one included only energy intake $(\mathrm{kJ})$ and the outcome variable DIT $(\mathrm{kJ} / \mathrm{h})$; the second model also included four confounding factors (percentage of males, BMI, age, and hours of DIT measurement).

Figure 2 represents Model 1 (coefficient 0.011, standard error 0.0013, $p<0.001$, 95\% confidence interval, (CI) 0.0083 ; 0.014) conducted for 19 studies [14,16-19,22,24,25,27,30-38] with a total of 54 treatment arms. Eight studies could not be included in the meta-analyses because they had missing values for one or more of the variables investigated in the model. This model shows that DIT $(\mathrm{kJ})$ increases significantly $(p<0.001)$ when the $\mathrm{kJ}$ content of meals increases, although this increase is of a small magnitude (coefficient 0.011 ). This model predicts that for every $100 \mathrm{~kJ}$ increase in energy intake, DIT increases by $1.1 \mathrm{~kJ} / \mathrm{h}$.

Model 2, adjusted for percentage of males, BMI, age, and hours of DIT measurement, also predicted a small but significant increase in DIT for every $\mathrm{kJ}$ intake (coefficient 0.012, standard error $0.0013, p<0.001$; CI: $0.0091 ; 0.014)$. This model predicts that for every $100 \mathrm{~kJ}$ increase in energy intake, DIT increases by $1.2 \mathrm{~kJ} / \mathrm{h}$. In this model, 16 studies were included with a total of $48 \mathrm{arms}$. Three studies included in model 1 were not included in model 2 because they had missing values for one or more of the variables investigated $[16,25,34]$. DIT accounted for $47.4 \%$ of the variance in Model 1 and $70.6 \%$ of the variance in Model 2. 


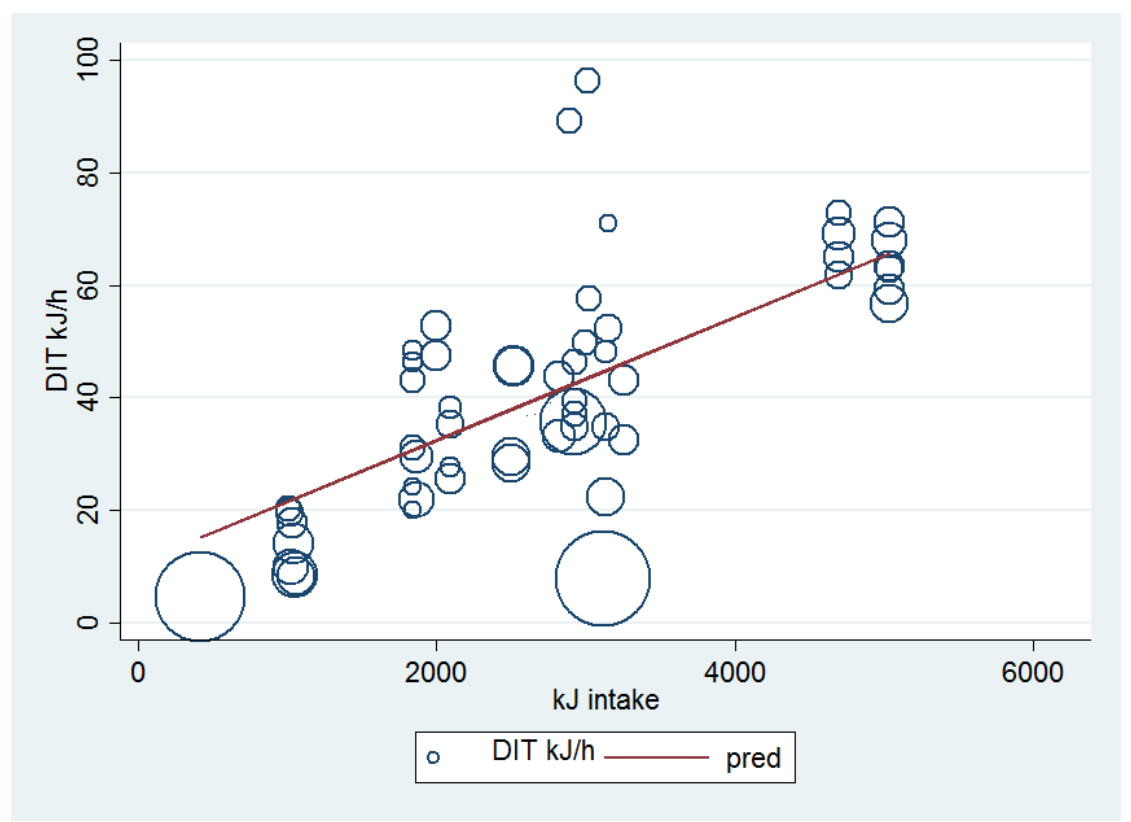

Figure 2. Mixed Model Meta Regression: univariate association between energy intake (kJ) and DIT $(\mathrm{kJ} / \mathrm{h})$ (Model 1). The Figure is composed of circles and a regression prediction line (in red) representing the outcome (DIT); each circle represents the value of DIT $(\mathrm{kJ} / \mathrm{h})$ for an arm of a study, and the size of the circle is inversely proportional to the standard error (SE) of the study. The influence of each study on the model depends on the size of the SE. Specifically, a study arm with a large SE is represented in the figure by a small circle, which means that this study arm had a small influence on the model whereas a study arm with a small SE is represented by a large circle, which means that this study arm had a large influence on the model.

\subsection{Influence of Macronutrient Composition on DIT}

Six studies [15,20,25,30,31,33] compared meals differing in macronutrient composition (fat vs. $\mathrm{CHO}$ and/or vs. protein). Five of these papers compared consuming a meal high in $\mathrm{CHO}$ with a meal high in fat. Nagai et al. [30] reported a higher DIT with a high CHO meal (3255 (306.5) kJ) compared to an isocaloric meal high in fat (3255 (306.5) kJ). DIT was $43.1(13.7) \mathrm{kJ} / \mathrm{h}$ for the high CHO meal and 32.6 (14.1) $\mathrm{kJ} / \mathrm{h}$ for the high fat meal, $p<0.05 \mathrm{for} \% / 3.5 \mathrm{~h} \mathrm{ECM} \mathrm{[30].} \mathrm{Blundell} \mathrm{et} \mathrm{al.} \mathrm{[33]} \mathrm{provided} \mathrm{isocaloric}$ comparisons (both meals contained $2092 \mathrm{~kJ}$ ) and found a statistically significant effect on DIT (high CHO milkshake: habitually high fat consumers $38.2(26.0) \mathrm{kJ} / \mathrm{h}$ and habitually low fat consumers 35.2 (15.6) kJ/h; high fat milkshake: habitually high fat consumers $27.5(28.9) \mathrm{kJ} / \mathrm{h}$ and habitually low fat consumers 25.6 (14.5) $\mathrm{kJ} / \mathrm{h}, p<0.05$ for $\mathrm{kJ} /$ day) [33]. The other two studies provided meals with only small differences in energy content (high CHO meal $2068 \mathrm{~kJ}$ and high fat meal $2093 \mathrm{~kJ}$ ) [20]; high CHO meal 3021 (1194.0) kJ and moderate fat meal 2996 (1167.4) kJ) [25]), and DIT was as follows: high CHO meal $54.6 \mathrm{~kJ} / \mathrm{h}$, high fat meal $27.8 \mathrm{~kJ} / \mathrm{h}$ [20]; high CHO meal $57.8(19.1) \mathrm{kJ} / \mathrm{h}$ and moderate fat meal 49.8 (21.6) $\mathrm{kJ} / \mathrm{h}$ [25]. No $p$ values were provided for these comparisons; therefore, it is not known if these comparisons were statistically significantly different $[20,25]$.

One study provided isocaloric comparisons and found no significant effect on DIT between high $\mathrm{CHO}$, low fat meals and low $\mathrm{CHO}$, high fat meals [31]. This study [31], which was described in Section 3.4 (higher energy vs. lower energy intake), provided the same group of subjects with high $\mathrm{CHO}$, low fat meals of two different energy contents (2510 kJ and $5040 \mathrm{~kJ})$, as well as low CHO, high fat meals of two different energy contents $(2520 \mathrm{~kJ}$ and $5040 \mathrm{~kJ})$ [31]. The DIT data were as follows: $5040 \mathrm{~kJ}$ high $\mathrm{CHO}$, low fat meal $71.2(15.5) \mathrm{kJ} / \mathrm{h}$ and $2520 \mathrm{~kJ}$ high $\mathrm{CHO}$, low fat meal $45.6(9.3) \mathrm{kJ} / \mathrm{h}$ vs. $5040 \mathrm{~kJ}$ low $\mathrm{CHO}$, high fat meal $68(12.4) \mathrm{kJ} / \mathrm{h}$ and $2520 \mathrm{~kJ}$ low $\mathrm{CHO}$, high fat meal $45.6(10.8) \mathrm{kJ} / \mathrm{h}$, $p>0.05$ for $\mathrm{kJ} / 5 \mathrm{~h}$ comparing high $\mathrm{CHO}$, low fat meals with low $\mathrm{CHO}$, high fat meals [31]. 
Additionally, only one study [15] compared consuming isocaloric meals rich in protein vs. fat vs. $\mathrm{CHO}$ in participants of the same sex (females consumed $2500 \mathrm{~kJ}$ and males $3000 \mathrm{~kJ}$ ). The high $\mathrm{CHO}$ and fat meals had the same DIT, whereas the high protein meal had a higher DIT (CHO meal $39.2 \mathrm{~kJ} / \mathrm{h}$, fat meal $39.2 \mathrm{~kJ} / \mathrm{h}$, and protein meal: $45.9 \mathrm{~kJ} / \mathrm{h}, p<0.01 \mathrm{for} \% / 5 \mathrm{~h} \mathrm{ECM} \mathrm{comparing} \mathrm{four} \mathrm{meals} \mathrm{Model} \mathrm{2,}$ adjusted for percentage of males, BMI, age, and hours of DIT measurement, also predicted a small but significant increase in DIT for every kJ intake (coefficient 0.012, standard error 0.0013, $p<0.001$; CI: $0.0091 ; 0.014)$. This model predicts that for every $100 \mathrm{~kJ}$ increase in energy intake, DIT increases by $1.2 \mathrm{~kJ} / \mathrm{h}$. In this model, 16 studies were included with a total of $48 \mathrm{arms}$. Three studies included in model 1 were not included in model 2 because they had missing values for one or more of the variables investigated [16,25,34]. DIT accounted for $47.4 \%$ of the variance in Model 1 and $70.6 \%$ of the variance in Model 2. (an alcohol meal was excluded for the purpose of this SR)) [15].

One study [38] investigated the effect of consuming an adequate level of protein (3131 kJ) with a low level of protein $(3114 \mathrm{~kJ})$ in meals with similar energy contents. This study found a higher DIT when an adequate level of protein was consumed compared to a lower level (adequate protein meal $22.4(5.7) \mathrm{kJ} / \mathrm{h}$; low protein meal $7.8(1.0) \mathrm{kJ} / \mathrm{h}, p=0.001 \mathrm{for} \mathrm{kJ} / 6 \mathrm{~h}$ and \%/6 h) [38].

Riggs et al. [24] undertook isocaloric comparisons of meals differing in the amount of fat provided and found a higher DIT after consuming a moderate fat meal $(1841 \mathrm{~kJ})$ than an isocaloric low fat meal $(1841 \mathrm{~kJ})$, where both meals were high in protein, among normal weight participants $(p<0.005$ for in \%ECM) but not in overweight or underweight participants [24]. The DIT results were as follows; normal weight: moderate fat meal 43.1 (19.2) kJ/h vs. low fat meal or $31.0(19.2) \mathrm{kJ} / \mathrm{h}$; overweight: moderate fat meal $48.4(20.0) \mathrm{kJ} / \mathrm{h}$ vs. low fat meal $46.3(18.8) \mathrm{kJ} / \mathrm{h}$; underweight: moderate fat meal $20.0(16.4) \mathrm{kJ} / \mathrm{h}$ or vs. low fat meal $24.2(15.6) \mathrm{kJ} / \mathrm{h} \mathrm{[24]}$.

\subsubsection{Long Chain Triglycerides vs. Medium Chain Triglycerides}

Three studies $[14,17]$ compared meals containing medium chain triglycerides (MCT) with long chain triglycerides (LCT) and all found a statistically higher DIT with meals containing MCT rather than meals containing LCT. Clegg et al. [17] provided two meals of the same energy content and macronutrient profiles but containing either MCT $(20 \mathrm{~g})$ or LCT $(18.4 \mathrm{~g})(1863 \mathrm{~kJ})$ [17] and found a significantly higher DIT with the MCT meal (MCT: 29.4 (8.4) $\mathrm{kJ} / \mathrm{h}$ vs. LCT: $21.9(7.9) \mathrm{kJ} / \mathrm{h}, p<0.005$ for \%/6 h ECM) [17].

Kasai et al. [14] conducted two studies comparing the effects of MCT vs. LCT. In study 1, three meals were administered ( $5 \mathrm{~g}$ of MCT and $5 \mathrm{~g}$ of LCT $(1029 \mathrm{~kJ})$ meal, $10 \mathrm{~g}$ MCT meal $(1013 \mathrm{~kJ})$, $10 \mathrm{~g}$ LCT meal (1046 kJ) [14]. DIT was significantly increased when MCT meals were consumed vs. LCT (10 g MCT meal 19.5 (14.1) kJ/h vs. $10 \mathrm{~g}$ LCT meal 8.4 (4.6) kJ/h, $p<0.01$ for \% ECM). Furthermore, DIT was significantly higher for the meal with both MCT and LCT than the one containing only LCT (5 g MCT, 5 g LCT meal 17.7 (10.8) kJ/h vs. 10 g LCT meal 8.4 (4.6) kJ/h, $p<0.01$ for \%/6 h ECM) [14].

In Study 2 [14], four meals were administered containing: mayonnaise with $5 \mathrm{~g}$ MCT (1042 kJ), mayonnaise with $5 \mathrm{~g}$ LCT $(1059 \mathrm{~kJ})$, margarine with $5 \mathrm{~g}$ MCT $(1004 \mathrm{~kJ})$, or margarine with $5 \mathrm{~g}$ LCT (1020 kJ) [14]. This study found a significantly higher DIT with meals containing MCT as opposed to LCT (meal with mayonnaise and MCT: $14.0(5.7) \mathrm{kJ} / \mathrm{h}$ vs. meal with mayonnaise and LCT: 8.2 (6.4) $\mathrm{kJ} / \mathrm{h}, p<0.05$ for \% ECM, meal with margarine and MCT $20.3(15.7) \mathrm{kJ} / \mathrm{h}$ vs. meal with margarine and LCT 9.8 (8.2) kJ/h, $p<0.05$ for \%/ 6 h ECM [14].

A fixed model meta-analysis was conducted with these three studies $[14,17]$ to compare DIT $(\mathrm{kJ} / \mathrm{h})$ for the MCT vs. LCT arms. Because Kasai et al. (2002) in study 2 [14] administered two interventions for MCT (margarine or mayonnaise) and two interventions for LCT (margarine or mayonnaise) to the same people, two forest plots are presented (one with only the margarine interventions and the other one with only the mayonnaise intervention arms). This avoids the effects of repetition of the same participants in both the margarine and mayonnaise studies. Both analyses found a significantly higher DIT when MCT was consumed compared to LCT ( $p=0.002$; Figure $3 \mathrm{a}, \mathrm{b})$. For both models the heterogeneity is $0 \%$ with $\mathrm{chi}^{2}=0.3$ and $p=0.9$ (Figure $3 \mathrm{a}$ ), and $\mathrm{chi}^{2}=0.7$ and $p=0.7$ (Figure $3 \mathrm{~b}$ ). 
The total sample size is 23 (for Figure 3a) or 22 (for Figure 3b) for each group of comparisons with the same people repeated for both interventions.

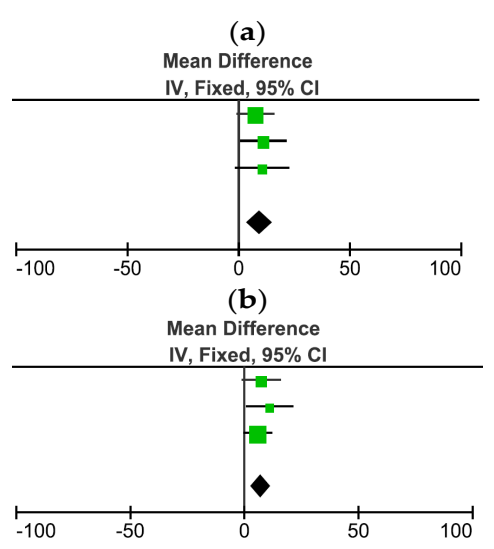

Figure 3. (a) Meta-analysis with fixed effect of the mean differences in DIT between MCT and LCT with the margarine trials of Kasai et al. Studies included in this meta-analysis are represented in the figure by symbols (green squares) and they are illustrated in the following order: Clegg et al. [17]-46.0\% weight; Kasai et al. [14]-study 1-31.6\% weight; Kasai et al. [14]-study 2 margarine trial-22.4\% weight [14]; (b) Meta-analysis with fixed effect of the mean differences in DIT between MCT and LCT with the mayonnaise trials of Kasai et al. Studies included in this meta-analysis are represented in the figure by symbols (green squares) and they are illustrated in the following order: Clegg et al. [17]-28.6\% weight; Kasai et al. [14]-study 1-19.6\% weight; Kasai et al. [14]-study 2-mayonnaise trial-51.8\% weight [14]. The $\%$ contribution of each study to the outcome is indicated as $\%$ weight.

\subsubsection{Monounsaturated Fat vs. Polyunsaturated Fat}

Two studies [18,39] compared meals containing monounsaturated fatty acids (MUFA), polyunsaturated fatty acids (PUFA), or saturated fatty acids (SFA). Casas-Agustench et al. [39] found a significantly higher DIT after the consumption of meals containing PUFA (mean (95\% CI) 2655 (2510-2799) kJ) or MUFA (mean (95\% CI) 2608 (2428-2788) kJ) compared to the one containing SFA (mean (95\% CI) $2599(2421-2278) \mathrm{kJ})$. The DIT as mean (95\% CI) was: PUFA meal $37.2(29.5-44.8) \mathrm{kJ} / \mathrm{h}$, MUFA meal 36.8 (30.5-43.0) kJ/h, and SFA meal $30.0(24.2-35.8) \mathrm{kJ} / \mathrm{h}, p<0.05$ for $\mathrm{kJ} / 5 \mathrm{~h}$ amongst the three interventions [39].

Contrary to this finding, the study by Piers et al. [18] found no significant difference in DIT (SFA meal 29.6 (10) kJ/h vs. MUFA meal 28.4 (10) $\mathrm{kJ} / \mathrm{h}, p>0.05$ for $\% / 5 \mathrm{~h} \mathrm{ECM}$ and $p>0.05$ for $\mathrm{kJ} / 5 \mathrm{~h}$ between meals containing MUFA or SFA (both meals: $2500 \mathrm{~kJ}$ ) [18].

\subsubsection{Structure of Fats}

Bendixen et al. [37] compared consuming meals with either a conventional fat (sunflower oil) or a chemically structured fat (rapeseed oil and octanoic acid by esterification with sodium methoxide) or a lipase-structured fat (rapeseed oil and octanoic acid by esterification with lipoxime IM) or a physically mixed fat (blending rapeseed oil and trioctanoate) [37]. The mean energy content of these four meals was 4698 (550.2) kJ [37]. This paper found a significant effect of fat structure on DIT with the highest DIT associated with the meal containing a chemically structured fat and the lowest with the meal having the conventional fat (conventional fat meal $61.8(15.2) \mathrm{kJ} / \mathrm{h}$, chemically structured fat meal $72.8(19.0) \mathrm{kJ} / \mathrm{h}$, lipase-structured fat meal $69.2(11.4) \mathrm{kJ} / \mathrm{h}$, and physically mixed fat meal $65(13.9) \mathrm{kJ} / \mathrm{h}$, $p=0.005$ for $\mathrm{kJ} / 5 \mathrm{~h}$ ) [37].

\subsection{Processed vs. Unprocessed Food}

Only one study [26] compared consuming two meals with different levels of processing. One meal was composed of whole food (multi-grain bread and cheddar cheese either as one and a half sandwiches 
or two sandwiches) and the other was composed of processed foods (white bread and a processed cheese either as one and a half sandwiches or two sandwiches) [26]. Subjects could choose to consume either one and a half sandwiches $(2520 \mathrm{~kJ})$ or two sandwiches $(3360 \mathrm{~kJ})$, and this choice was kept constant for both trials, thus the two trials were isocaloric for the same participant. There was a highly significant increase in DIT after consuming the whole food meal compared to the more processed meal (whole food meal: 99.4 (40.7) kJ/h; processed meal: $63.9(35.6) \mathrm{kJ} / \mathrm{h}, p<0.001$ for total $\mathrm{kJ}$ and $p<0.01$ for total \% ECM [26]).

\subsection{One Bolus Event vs. Isocaloric Smaller Frequent Meals}

Four studies [27,32,34,35] compared administering a meal as a bolus event versus splitting the same meal into two [32], three [34], four [35] or six [27] smaller equal meals or snacks to be consumed throughout the morning. The time between multiple meals was $180 \mathrm{~min}$ [32], $60 \mathrm{~min}$ [35], or $30 \mathrm{~min}$ [27,34]. Kinabo and Durbin [32] compared two eating patterns using two different meal compositions: high $\mathrm{CHO}$, low fat and low $\mathrm{CHO}$, high fat. All four studies had the same participants perform both interventions (total $n=55$ ). The energy density was as follows: $5040 \mathrm{~kJ}$ or $2510 \mathrm{~kJ} \times 2$ either as high $\mathrm{CHO}$ and low fat meal or low $\mathrm{CHO}$ and high fat meal [32]; 3150 or $1050 \mathrm{~kJ} \times 3$ [34]; $2823.4 \mathrm{~kJ}$ or $705.8 \mathrm{KJ} \times 4$ meals [35]; and $3138 \mathrm{~kJ}$ or $523 \mathrm{~kJ} \times 6$ [27].

Two studies [32,34] found no significant difference in DIT between the bolus and the isocaloric smaller frequent meals event (high $\mathrm{CHO}$, low fat meal as bolus 62.8 (13.2) $\mathrm{kJ} / \mathrm{h}$ vs. smaller frequent meals event 63.5 (11.7) kJ/h, $p>0.05$ for $\mathrm{kJ} / 6 \mathrm{~h}$; low $\mathrm{CHO}$, high fat meal as bolus 59.3 (11.5) kJ/h vs. smaller frequent meals event $56.7(8.0) \mathrm{kJ} / \mathrm{h}, p>0.05$ for $\mathrm{kJ} / 6 \mathrm{~h}$ [32]; bolus 71 (31.5) $\mathrm{kJ} / \mathrm{h}$ vs. smaller frequent meals 52.3 (15.3) $\mathrm{kJ} / \mathrm{h}, p>0.05$ for $\mathrm{kJ} / 2 \mathrm{~h}$ [34]).

The other two studies found a significantly higher DIT when the meals were consumed as a bolus event compared to smaller frequent meal events: bolus $43.8(18.4) \mathrm{kJ} / \mathrm{h}$ vs. smaller frequent meals 33.2 (15.5) $\mathrm{kJ} / \mathrm{h}, p<0.05$ for \%/4 h ECM [35]; bolus 48.2 (16.93) $\mathrm{kJ} / \mathrm{h}$ vs. smaller frequent meals 34.9 (12.3) $\mathrm{kJ} / \mathrm{h}, p<0.05$ for $\mathrm{kJ} / 5 \mathrm{~h}$ [27]).

In order to clarify these discrepancies, a meta-analysis of the mean differences between bolus and smaller frequent meal event trials with fixed effects was conducted in RevMan to find the overall effect on DIT [32]. For these analyses, DIT was compared in $\mathrm{kJ} / \mathrm{h}$ in order to standardize the units between studies. The forest plot shows (Figure 4) the mean of the difference between bolus and smaller frequent meal event trials for each study. The overall mean of the difference is positive, which means that the DIT was lower in the smaller frequent meals event trials compared to the bolus trial. This overall effect on DIT was significant $(p=0.02)$. The heterogeneity was $14 \%$, chi ${ }^{2}=4.6$ and $p=0.3$.

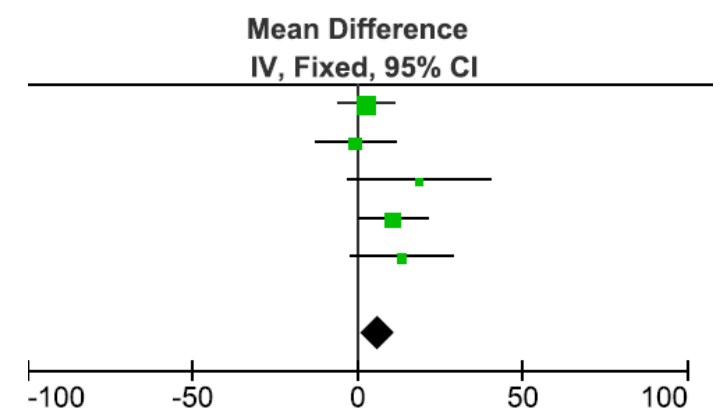

Figure 4. Meta-analysis: mean differences in DIT between bolus vs. smaller frequent meals event (suc as snacking). Studies included in this meta-analysis are represented in the figure by symbols (green squares) and they are illustrated in the following order: Kinabo and Durbin et al. [32]-Paper B low $\mathrm{CHO}$, high fat meal-37.6\% Weight; Kinabo and Durbin et al. [32]-Paper B high CHO, low fat meal-19.0\% weight; Vaz et al. [34]-6.0\% weight; Allirot et al. [35]-25.5\% weight; Tai et al. [27]-11.8\% weight. Weight refers to amount of influence that the study exerts on the meta-analyses. The $\%$ contribution of each study to the outcome is indicated as \% weight. 
Table 2. Consumption of meals after an overnight fast and DIT.

\begin{tabular}{|c|c|c|c|c|c|}
\hline $\begin{array}{l}\text { Reference and DIT } \\
\text { Measurement }\end{array}$ & $\begin{array}{l}\text { Energy Ingested (kJ) and \% } \\
\text { Energy from Macronutrients }\end{array}$ & DIT (kJ) & $\begin{array}{l}\text { DIT \% Energy Content of } \\
\text { the Meal }\end{array}$ & DIT \% above Baseline & Conclusions \\
\hline \multicolumn{6}{|c|}{ Higher vs. lower energy intake } \\
\hline $\begin{array}{l}\text { Kinabo and Durnin [31] } \\
\text { Paper } \mathbf{A}^{++} \\
\text {DIT }=\text { open circuit indirect } \\
\text { calorimetry using Douglas } \\
\text { bag for } 5 \text { h; DIT measured for } \\
10 \text { min, every } 10 \text { min for } \\
3 \text { collections then every } \\
20 \text { min for } 5 \text { collections }\end{array}$ & $\begin{array}{l}\text { (a and b) } 2520 \mathrm{~kJ} \\
(\mathrm{c} \text { and d) } 5040 \mathrm{~kJ} \\
(\mathrm{a} \text { and c) } 70 \% \mathrm{CHO}, 11 \% \text { protein, } \\
19 \% \text { fat } \\
\text { (b and d) } 24 \% \mathrm{CHO}, 11 \% \text { protein } \\
\text { and } 65 \% \text { fat }\end{array}$ & $\begin{array}{l}\text { (a) } 45.6^{\dagger}(9.3)^{+} \mathrm{kJ} / \mathrm{h} \\
\text { (b) } 45.6^{+}(10.8)^{+} \mathrm{kJ} / \mathrm{h} \\
\text { (c) } 71.2^{+}(15.5)^{+} \mathrm{kJ} / \mathrm{h} \\
\text { (d) } 68^{+}(12.4)^{+} \mathrm{kJ} / \mathrm{h} \\
\mathrm{NS}(\mathrm{a} \text { and c vs. b and } \mathrm{d} \text { for } \mathrm{kJ} / 5 \mathrm{~h} \text { ) } \\
* * * * \text { a and b vs. c and d for } \mathrm{kJ} \text { or } \\
\mathrm{kcal} / 5 \mathrm{~h} \text { ) } \\
\text { NS (all four meals compared for } \\
\mathrm{kJ} \text { or kcal } / 5 \mathrm{~h} \text { ) }\end{array}$ & $\begin{array}{l}\text { (a) } 1.8^{+}(0.4)^{+} \% / \mathrm{h} \\
\text { (b) } 1.8^{+}(0.5)^{+} \% / \mathrm{h} \\
\text { (c) } 1.4^{+}(0.3)^{+} \% / \mathrm{h} \\
\text { (d) } 1.4^{+}(0.2)^{+} \% / \mathrm{h}\end{array}$ & $\begin{array}{l}\text { (a) } 21(4.3)^{+\%} \% \\
\text { (b) } 21(5.8)^{+\%} \\
\text { (c) } 33(7.7)^{+} \% \\
\text { (d) } 33(6.2)^{+\%}\end{array}$ & $\begin{array}{l}\text { No significant difference } \\
\text { between meals differing on } \\
\text { macronutrient compositions. } \\
\text { Significantly higher DIT for } \\
\text { meals with higher energy } \\
\text { intake compared to lower } \\
\text { energy intake. }\end{array}$ \\
\hline $\begin{array}{l}\text { Hill et al. [23] } \\
\text { DIT = indirect calorimetry for } \\
3 \text { h; DIT measured every } \\
30 \text { min }\end{array}$ & $\begin{array}{l}\text { (a) } 2092 \mathrm{~kJ}^{+} \\
\text {(b) } 4184 \mathrm{~kJ}^{+} \\
\text {(c) } 6276 \mathrm{~kJ}^{+} \\
50 \% \mathrm{CHO}, 16 \% \text { protein, } 34 \% \mathrm{fat}\end{array}$ & & & $\begin{array}{l}\text { (a) high and low } \mathrm{VO}_{2} \\
\text { group: less than } 10 \% \\
\text { (b) high } \mathrm{VO}_{2} \max 23 \% \text { low } \\
\mathrm{VO}_{2} \max 19 \% \\
\text { (c) high } \mathrm{VO}_{2} \max 41 \% \text {, low } \\
\mathrm{VO}_{2} \max 26 \% \\
p \text { value } \mathrm{NP}\end{array}$ & $\begin{array}{l}\text { An increase in meal size } \\
\text { increased DIT. Unclear if } \\
\text { effect was significant. }\end{array}$ \\
\hline $\begin{array}{l}\text { Martin et al. [36] } \\
\text { DIT = ventilated hood } \\
\text { indirect calorimetry for } 4 \mathrm{~h} \text {; } \\
\text { DIT measured every hour }\end{array}$ & $\begin{array}{l}\text { (a) } 418 \mathrm{~kJ}, 62 \% \mathrm{CHO}, 34.4 \% \text { fat, } \\
3.6 \% \text { protein } \\
\text { (b) } 2920 \mathrm{~kJ}, 67 \% \mathrm{CHO}, 24.6 \% \text { fat, } \\
8.4 \% \text { protein }\end{array}$ & $\begin{array}{l}\text { (a) } 4.5^{\dagger}(1.4)^{\dagger} \mathrm{kJ} / \mathrm{h} \\
\text { (b) } 35.6^{\dagger}(2.6)^{\dagger} \mathrm{kJ} / \mathrm{h}\end{array}$ & $\begin{array}{l}\text { (a) } 1.1(0.3) \% / \mathrm{h} \\
\text { (b) } 1.2(0.1) \% / \mathrm{h} \\
p \text { value NP }\end{array}$ & & $\begin{array}{l}\text { No difference on DIT between } \\
\text { low energy, moderate fat } \\
\text { meal, and high energy, } \\
\text { low fat meal. }\end{array}$ \\
\hline $\begin{array}{l}\text { Bennet et al. [21] } \\
\text { DIT = ventilated hood } \\
\text { indirect calorimetry for } 6 \mathrm{~h} \text {; } \\
\text { continuously }\end{array}$ & $\begin{array}{l}\text { NP kJ } \\
\text { (a) } 55 \% \mathrm{CHO}, 30 \% \text { fat, } \\
15 \% \text { protein } \\
\text { (b) same meal as above plus } 50 \mathrm{~g} \\
\text { of fat (addition of } 1881 \mathrm{~kJ} \\
\text { compared to breakfast (a)) }\end{array}$ & & $\begin{array}{l}\text { (a) } 1.3^{+}(0.3)^{+} \% / \mathrm{h} \\
\text { (b) } 1.2^{+}(0.40)^{+} \% / \mathrm{h} \\
\text { NS (a vs. b for all subjects } \\
\text { (trained and untrained) only } \\
\text { included untrained for this SR) }\end{array}$ & & $\begin{array}{l}\text { No significant difference in } \\
\text { DIT between high fat meal } \\
\text { and normal fat meal for the } \\
\text { overall subjects (trained } \\
\text { vs. untrained). }\end{array}$ \\
\hline $\begin{array}{l}\text { Segal et al. [22] } \\
\text { DIT = open circuit indirect } \\
\text { calorimetry for } 3 \mathrm{~h} \text {; DIT } \\
\text { measured for at least } 6 \mathrm{~min} \\
\text { periods every } 30 \mathrm{~min}\end{array}$ & $\begin{array}{l}\text { (a) } 35 \% \text { of each man } 24 \mathrm{~h} \text { RMR } \\
\text { ( } 2889 * \mathrm{~kJ}) \mathrm{NP} \text { macronutrients } \\
\text { (b) } 3013 \mathrm{~kJ}{ }^{\dagger}, 55 \% \mathrm{CHO}, 24 \% \\
\text { protein, } 21 \% \text { fat }\end{array}$ & $\begin{array}{l}\text { (a) } 89.3^{+}(17.6)^{+} \mathrm{kJ} / \mathrm{h} \\
\text { (b) } 96.3^{+}(17.6)^{+} \mathrm{kJ} / \mathrm{h}\end{array}$ & $\begin{array}{l}\text { (a) } 3.2^{+}(0.8)^{+} \% / \mathrm{h} \\
\text { (b) } 3.3^{+}(0.4)^{+} \% / \mathrm{h} \\
\text { NS (a vs. b } \% / 3 \mathrm{~h} \text { ) }\end{array}$ & $\begin{array}{l}\text { (a) } 11.9 \% \\
\text { (b) } 12.9 \%\end{array}$ & N.A. \\
\hline \multicolumn{6}{|c|}{ Meals varying in macronutrient composition } \\
\hline $\begin{array}{l}\text { Nagai et al. [30] } \\
\text { DIT = open circuit indirect } \\
\text { calorimetry for } 3.5 \text { h; DIT } \\
\text { measured for } 6 \text { min every } \\
30 \text { min }\end{array}$ & $\begin{array}{l}3255(306.5)^{\dagger} \mathrm{kJ} \\
\text { (a) } 70 \% \mathrm{CHO}, 10 \% \text { protein, } \\
20 \% \text { fat } \\
\text { (b) } 20 \% \mathrm{CHO}, 10 \% \text { protein, } \\
70 \% \text { fat }\end{array}$ & $\begin{array}{l}\text { (a) } 43.1^{+}(13.7)^{+} \mathrm{kJ} / \mathrm{h} \\
\text { (b) } 32.6^{+}(14.1)^{\dagger} \mathrm{kJ} / \mathrm{h} \\
* \text { (a vs. b for kJ/3.5 h) }\end{array}$ & $\begin{array}{l}\text { (a) } 1.3^{+}(0.4)^{+} \% / \mathrm{h} \\
\text { (b) } 1.0^{+}(0.4)^{+} \% / \mathrm{h} \\
\left.{ }^{*} \text { (a vs. b for } \% / 3.5 \mathrm{~h} \mathrm{ECM}\right)\end{array}$ & $\begin{array}{l}\text { (a) } 1.7(0.7)+\% \\
\text { (b) } 1.3(0.4)+\% \\
{ }^{*} \text { (a vs. b for } \% \mathrm{AB} \text { ) }\end{array}$ & $\begin{array}{l}\text { DIT was significantly higher } \\
\text { in low fat meal compared to } \\
\text { high fat meal. }\end{array}$ \\
\hline
\end{tabular}


Table 2. Cont

\begin{tabular}{|c|c|c|c|c|c|}
\hline $\begin{array}{l}\text { Reference and DIT } \\
\text { Measurement }\end{array}$ & $\begin{array}{l}\text { Energy Ingested (kJ) and \% } \\
\text { Energy from Macronutrients }\end{array}$ & DIT (kJ) & $\begin{array}{l}\text { DIT \% Energy Content of } \\
\text { the Meal }\end{array}$ & DIT \% above Baseline & Conclusions \\
\hline \multicolumn{6}{|c|}{ Meals varying in macronutrient composition } \\
\hline $\begin{array}{l}\text { Blundell et al. [33] } \\
\text { DIT = ventilated hood } \\
\text { indirect calorimetry for } \\
3 \text { h continuously }\end{array}$ & $\begin{array}{l}2092 \mathrm{~kJ} \\
\text { (a) } 19.9 \% \text { CHO, } 78.8 \% \text { fat, } \\
1.3 \% \text { protein } \\
\text { (b) } 90.4 \% \text { CHO, } 1.3 \% \text { fat, } \\
8.3 \% \text { protein }\end{array}$ & $\begin{array}{l}\text { (a) high fat consumers } 27.5^{+} \\
(28.9)^{\dagger} \mathrm{kJ} / \mathrm{h} \text {; low fat consumers } \\
25.6^{\dagger}(14.5)^{\dagger} \mathrm{kJ} / \mathrm{h} \\
\text { (b) high fat consumers } 38.2^{+} \\
(26.0)^{\dagger} \mathrm{kJ} / \mathrm{h} \text {; low fat consumers } \\
35.2^{+}(15.6)^{\dagger} \mathrm{KJ} / \mathrm{h} \\
{ }^{*} \text { (a vs. b for kJ/day) }\end{array}$ & $\begin{array}{l}\text { (a) high fat consumers } 1.3^{+}(1.4) \\
{ }^{\dagger} \% / \mathrm{h} ; \text { low fat consumers } 1.2^{\dagger} \\
(0.7)^{\dagger} \% / \mathrm{h} \\
\text { (b) high fat consumers } 1.7^{\dagger}(1.2) \\
{ }^{+} \% / \mathrm{h} \text {; low fat consumers } 1.7^{+} \\
(0.7)^{+} \% / \mathrm{h}\end{array}$ & $\begin{array}{l}\text { (a) high fat consumers } \\
10.2^{+}(10.8)^{\dagger} \% \\
\text { low fat consumers } 9.9^{+} \\
(5 .)^{+} \% \\
\text { (b) high fat consumers } \\
14.2^{+}(9.7)^{+} \% \\
\text { low fat consumers13.6 } \\
(6.0)^{+} \%\end{array}$ & $\begin{array}{l}\text { The consumption of a } \\
\text { high-carbohydrate meal was } \\
\text { significantly associated with } \\
\text { an increased DIT compared to } \\
\text { a high fat meal }\end{array}$ \\
\hline $\begin{array}{l}\text { Bowden and McMurray [20] } \\
\text { DIT = open circuit spirometry } \\
\text { for } 5 \text { h; DIT measured for } 10 \\
\text { min periods every } 30 \mathrm{~min}\end{array}$ & $\begin{array}{l}\text { (a) } 2068 \mathrm{~kJ}, 76 \% \text { CHO, } 5 \% \text { protein, } \\
23 \% \text { fat } \\
\text { (b) } 2093 \mathrm{~kJ} \text { (fixed amount), } 21 \% \\
\mathrm{CHO}, 8 \% \text { protein, } 72 \% \mathrm{fat}\end{array}$ & $\begin{array}{l}\text { (a) } 54.6^{+} \mathrm{kJ} / \mathrm{h} \\
\text { (b) } 27.8^{+} \mathrm{kJ} / \mathrm{h}\end{array}$ & $\begin{array}{l}\text { (a) } 2.6^{+} \% / \mathrm{h} \\
\text { (b) } 1.3^{+} \% / \mathrm{h} \\
p \text { value NP }\end{array}$ & $\begin{array}{l}\text { (a) } 26.2^{+} \% \\
\text { (b) } 13.4^{+} \%\end{array}$ & $\begin{array}{l}\text { No significant difference on } \\
\text { total energy expenditure } \\
\text { between high } \mathrm{CHO} \text { and high } \\
\text { fat meal. }\end{array}$ \\
\hline $\begin{array}{l}\text { Thyfault et al. [25] } \\
\text { DIT = indirect calorimetry } \\
\text { with face mask for } 4 \mathrm{~h} \text {; DIT } \\
\text { measured continuously with } \\
\text { measurements averaged over } \\
15 \text { min periods for } 1 \mathrm{~h} \text { then for } \\
30 \text { min periods for the } \\
\text { remaining hours }\end{array}$ & $\begin{array}{l}\text { (a) } 3021(1194.0)^{\dagger} \mathrm{kJ}, 79 \% \mathrm{CHO} \text {, } \\
20 \% \text { protein, } 1 \% \mathrm{fat} \\
\text { (b) } 2996(1167.4)^{\dagger} \mathrm{kJ}, 37 \% \mathrm{CHO} \text {, } \\
18 \% \text { protein, } 45 \% \mathrm{fat}\end{array}$ & $\begin{array}{l}\text { (a) } 57.8^{+}(19.1)^{+} \mathrm{kJ} / \mathrm{h} \text { or } 1.0(0.3) \\
{ }^{+} \mathrm{kJ} / \mathrm{FFM} / \mathrm{h} \text { or } 0.7(0.9)^{+} \\
\mathrm{kJ} / \mathrm{BM} / \mathrm{h} \\
(\mathrm{b}) 49.8^{+}(21.6)^{+} \mathrm{kJ} / \mathrm{h} \text { or } 0.8(0.3) \\
{ }^{+} \mathrm{kJ} / \mathrm{FFM} / \mathrm{h} \text { or } 0.6(0.9)^{+} \\
\mathrm{kJ} / \mathrm{BM} / \mathrm{h} \\
p \text { value NP }\end{array}$ & $\begin{array}{l}\text { (a) } 1.9^{\dagger}(0.6)^{+} \% / \mathrm{h} \\
\text { (b) } 1.7^{\dagger}(0.7)+\% / \mathrm{h} \\
p \text { value NP }\end{array}$ & & N.A. \\
\hline $\begin{array}{l}\text { Raben et al. [15] } \\
\text { DIT = indirect calorimetry } \\
\text { with an open-circuit } \\
\text { ventilated hood system; } \\
\text { continuously for } 5 \mathrm{~h} \text { with } \\
5 \text { min breaks every } \mathrm{h} \\
\text { if needed }\end{array}$ & $\begin{array}{l}2500 \mathrm{~kJ} \text { for } \mathrm{f}, 3000 \mathrm{~kJ} \text { for } \mathrm{m} \\
\text { (a) } 37.2 \% \mathrm{CHO}, 31.8 \% \text { protein, } \\
31.1 \% \mathrm{fat} \\
\text { (b) } 23.9 \% \mathrm{CHO}, 11.6 \% \text { protein, } \\
64.6 \% \mathrm{fat} \\
\text { (c) } 65.4 \% \mathrm{CHO}, 12.2 \% \text { protein, } \\
23.7 \% \text { fat }\end{array}$ & $\begin{array}{l}\text { (a) } 45.9^{+} \mathrm{kJ} / \mathrm{h} \\
\text { (b) } 39.2^{+} \mathrm{kJ} / \mathrm{h} \\
\text { (c) } 39.2^{+} \mathrm{kJ} / \mathrm{h}\end{array}$ & $\begin{array}{l}\text { (a) } 1.7 \% / \mathrm{h} \\
\text { (b) } 1.4 \% / \mathrm{h} \\
\text { (c) } 1.4 \% / \mathrm{h} \\
* * \text { (a vs. b vs. c vs. also meal } \\
\text { with alcohol excluded for this } \\
\text { SR for } \% / 5 \mathrm{~h} \text { ) }\end{array}$ & & $\begin{array}{l}\text { Significant difference in DIT } \\
\text { between the different meal } \\
\text { types administered. Protein } \\
\text { had a higher DIT compared to } \\
\text { fat and CHO meals. }\end{array}$ \\
\hline $\begin{array}{l}\text { Petzke and Klaus [38] } \\
\text { DIT = indirect calorimetry } \\
\text { ventilated-hood system for } \\
6 \mathrm{~h} ; 3 \times 30 \mathrm{~min} \text { measurements } \\
\text { (first } 5-10 \text { min discarded) at } \\
30,150 \text {, and } 270 \text { min }\end{array}$ & $\begin{array}{l}\text { (a) } 3114 \mathrm{~kJ}, 35.4 \% \mathrm{CHO}, 3.9 \% \\
\text { protein, } 60.7 \% \text { fat } \\
\text { (b) } 3131 \mathrm{~kJ}, 27.8 \% \mathrm{CHO}, 11.4 \% \\
\text { protein, } 60.8 \% \text { fat }\end{array}$ & $\begin{array}{l}\text { (a) } 7.8^{+}(1.0)^{+} \mathrm{kJ} / \mathrm{h} \\
\text { (b) } 22.4^{\dagger}(5.7)^{+} \mathrm{kJ} / \mathrm{h} * * * \text { (a vs. b } \\
\text { for } \mathrm{kJ} / 6 \mathrm{~h} \text { ) }\end{array}$ & $\begin{array}{l}\text { (a) } 1.5^{+}(0.2)^{\dagger} \% / \mathrm{h} \\
\text { (b) } 4.3^{\dagger}(1.1)^{\dagger} \% / \mathrm{h} \\
* * * \text { (a vs. b for } \% / 6 \mathrm{~h} \text { ) }\end{array}$ & $\begin{array}{l}\text { (a) } 3.6^{+}(0.5)^{+} \% \\
\text { (b) } 9.7^{+}(2.5)^{+} \%\end{array}$ & $\begin{array}{l}\text { DIT was significantly higher } \\
\text { in adequate protein meal } \\
\text { compared to low } \\
\text { protein meal. }\end{array}$ \\
\hline $\begin{array}{l}\text { Riggs et al. [24] } \\
\text { DIT = indirect calorimetry for } \\
3.5 \text { h; DIT measured every } \\
30 \mathrm{~min}\end{array}$ & $\begin{array}{l}1841 \mathrm{~kJ}^{\dagger} \\
\text { (a) } 23 \% \mathrm{CHO}^{+++} ; 34 \% \text { protein, } \\
43 \% \text { fat } \\
\text { (b) } 48 \% \mathrm{CHO}^{+++} ; 28 \% \text { protein, } \\
24 \% \text { fat }\end{array}$ & 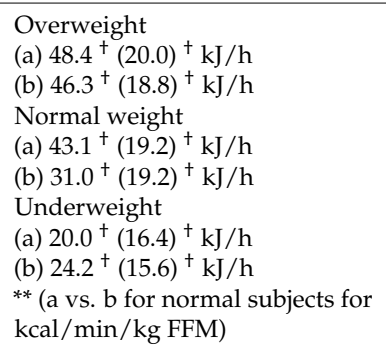 & $\begin{array}{l}\text { Overweight } \\
\text { (a) } 2.6^{+}(0.2)^{+} \% / \mathrm{h} \\
\text { (b) } 2.5^{+}(1.0)^{+} \% / \mathrm{h} \\
\text { Normal weight } \\
\text { (a) } 2.3^{+}(1.0)^{+} \% / \mathrm{h} \\
\text { (b) } 1.7^{+}(1.0)^{+} \% / \mathrm{h} \\
\text { Underweight } \\
\text { (a) } 1.1^{+}(0.9)^{+} \% / \mathrm{h} \\
\text { (b) } 1.3^{+}(0.9)^{+} \% / \mathrm{h} \\
* * \text { (a vs. b for normal subjects } \\
\text { for } \% / 3.5 \mathrm{~h} \text { ) }\end{array}$ & & $\begin{array}{l}\text { Significantly higher DIT for } \\
\text { the high protein, high fat } \\
\text { meal in normal } \\
\text { weight subjects. }\end{array}$ \\
\hline
\end{tabular}


Table 2. Cont.

\begin{tabular}{|c|c|c|c|c|c|}
\hline $\begin{array}{l}\text { Reference and DIT } \\
\text { Measurement }\end{array}$ & $\begin{array}{l}\text { Energy Ingested (kJ) and \% } \\
\text { Energy from Macronutrients }\end{array}$ & DIT (kJ) & $\begin{array}{l}\text { DIT \% Energy Content of } \\
\text { the Meal }\end{array}$ & DIT \% above Baseline & Conclusions \\
\hline \multicolumn{6}{|c|}{ Meals varying in macronutrient composition } \\
\hline $\begin{array}{l}\text { Clegg et al. [17] } \\
\text { DIT = ventilated hood } \\
\text { indirect calorimetry for } 6 \mathrm{~h} \text {; } \\
\text { measured for } 15 \text { min every } \\
30 \text { min }\end{array}$ & $\begin{array}{l}1863 \mathrm{~kJ} \\
35.5 \% \mathrm{CHO} \text {, protein } 19.9 \% \text {, } \\
44.6 \% \text { fat }\end{array}$ & $\begin{array}{l}\text { (a) } 21.9^{+}(7.9)^{+} \mathrm{kJ} / \mathrm{h} \\
\text { (b) } 29.4^{+}(8.4)^{+} \mathrm{kJ} / \mathrm{h} \\
* * \text { (a vs. b for kcal } 6 \mathrm{~h} \text { ) }\end{array}$ & $\begin{array}{l}\text { (a) } 1.2^{+}(0.4)^{+} \% / \mathrm{h} \\
\text { (b) } 1.6^{+}(0.5)^{+} \% / \mathrm{h} \\
* * \text { (a vs. b for } \% / 6 \mathrm{~h} \text { ) }\end{array}$ & & $\begin{array}{l}\text { Pepper sunflower oil had a } \\
\text { significantly lower DIT than } \\
\text { pepper MCT oil intervention. }\end{array}$ \\
\hline $\begin{array}{l}\text { Kasai et al. [14] study } 1 \\
\text { DIT = indirect calorimetry } \\
\text { Aeromonitor AE-300S; } \\
\text { DIT measured for } 6 \mathrm{~h} \text { at } \\
1 \mathrm{~h} \text { intervals }\end{array}$ & $\begin{array}{l}\text { (a) } 1046 \mathrm{~kJ}^{+} \\
\text {(b) } 1029 \mathrm{~kJ}^{+} \\
\text {(c) } 1013 \mathrm{~kJ}^{+} \\
43 \% \mathrm{CHO}, 21 \% \text { protein, } 36 \% \text { fat }\end{array}$ & $\begin{array}{l}\text { (a) } 8.4^{+}(4.6)^{+} \mathrm{kJ} / \mathrm{h} \text { or } 0.1^{\dagger} \\
(0.07)^{\dagger} \mathrm{kJ} / \mathrm{kg} / \mathrm{h} \\
\text { (b) } 17.7^{\dagger}(10.8)^{+} \mathrm{kJ} / \mathrm{h} \text { or } 0.3^{+} \\
(0.2)^{+} \mathrm{kJ} / \mathrm{kg} / \mathrm{h} \\
\text { (c) } 19.5^{+}(14.1)^{+} \mathrm{kJ} / \mathrm{h} \text { or } 0.3^{+} \\
(0.2)^{\dagger} \mathrm{kJ} / \mathrm{kg} / \mathrm{h} \\
* * \text { (a vs. b for cal } / \mathrm{kg} / 6 \mathrm{~h}) \\
* * \text { (a vs. c for cal } / \mathrm{kg} / 6 \mathrm{~h}) \\
\mathrm{NS} \text { (b vs. c for cal } / \mathrm{kg} / 6 \mathrm{~h})\end{array}$ & $\begin{array}{l}\text { (a) } 0.8^{+}(0.5)^{+} \% / \mathrm{h} \\
\text { (b) } 1.7^{+}(1 .)^{+} \% / \mathrm{h} \\
\text { (c) } 1.9^{+}(1.4)^{+} \% / \mathrm{h} \\
* * \text { (a vs. b for } \% / 5 \mathrm{~h}) \\
* * \text { (a vs. c for } \% / 5 \mathrm{~h}) \\
\text { NS (b vs. c for kJ/5 h) }\end{array}$ & $\begin{array}{l}\text { (a) } 2.8^{+}(1.7)^{+} \% \\
\text { (b) } 6.3^{+}(3.9)^{+} \% \\
\text { (c) } 7.3^{+}(5.2)^{+} \%\end{array}$ & $\begin{array}{l}\text { Significant increase in DIT } \\
\text { when a liquid meal } \\
\text { containing MCT was } \\
\text { consumed compared to a } \\
\text { meal with LCT. }\end{array}$ \\
\hline $\begin{array}{l}\text { Kasai et al. [14] study } 2 \\
\text { DIT = indirect calorimetry } \\
\text { Aeromonitor AE-300S; DIT } \\
\text { measured for } 6 \text { h at } \\
1 \text { h intervals }\end{array}$ & $\begin{array}{l}\text { (a) } 1059 \mathrm{~kJ}^{+} \\
\text {(b) } 1042 \mathrm{~kJ}^{+} \\
\text {(c) } 1020 \mathrm{~kJ}^{+} \\
\text {(d) } 1004 \mathrm{~kJ}^{+} 50 \% \mathrm{CHO}, \\
10 \% \text { protein, } 40 \% \mathrm{fat}\end{array}$ & 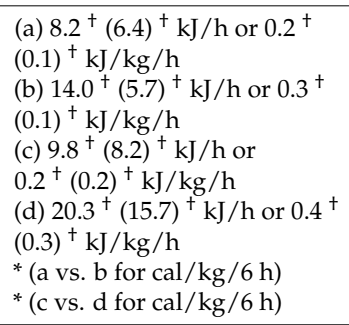 & $\begin{array}{l}\text { (a) } 0.8^{+}(0.6)^{+} \% \mathrm{~h} \\
\text { (b) } 1.3^{+}(0.5)^{+} \% \mathrm{~h} \\
\text { (c) } 1.0^{+}(0.8)^{+} \% \mathrm{~h} \\
\text { (d) } 2.0^{+}(1.6)^{+} \% \mathrm{~h} \\
{ }^{*} \text { (a vs. b for } \% / 5 \mathrm{~h} \text { ) } \\
* \text { (c vs. d for } \% / 5 \mathrm{~h} \text { ) }\end{array}$ & $\begin{array}{l}\text { (a) } 3.9^{+}(3.0)^{+} \% \\
\text { (b) } 6.8^{+}(2.7)^{+} \% \\
\text { (c) } 4.7^{+}(3.9)^{+} \% \\
\text { (d) } 10.5^{+}(7.9)^{+} \%\end{array}$ & $\begin{array}{l}\text { Significant increase in DIT in } \\
\text { meals containing mayonnaise } \\
\text { or margarine with MCT } \\
\text { compared to LCT. }\end{array}$ \\
\hline $\begin{array}{l}\text { Casas-Agustench et al. [39] } \\
\text { DIT = open circuit indirect } \\
\text { calorimetry with a canopy } \\
\text { system for } 5 \text { h continuously }\end{array}$ & $\begin{array}{l}\text { Mean }(95 \% \text { CI }) \\
\text { (a) } 2655(2510-2799) \mathrm{kJ}, 36.4 \\
\text { (35.9-36.7)\% CHO, 11.7 } \\
\text { (11.4-11.9)\% protein, } 51.9(95 \% \mathrm{CI} \\
51.7-52.1) \% \text { fat } \\
\text { (b) } 2608(2428-2788) \mathrm{kJ}, \\
37(95 \% \mathrm{CI} 36.6-37.4) \% \mathrm{CHO}, \\
11.3(95 \% \text { CI } 10.6-11.9) \% \text { protein, } \\
51.7(95 \% \text { CI } 51.3-52.0) \% \text { fat } \\
\text { (c) } 2599(2421-2278) \mathrm{kJ}, \\
37.1(95 \% \text { CI } 36.4-37.7) \% \text { CHO, } \\
11.2(95 \% \text { CI } 10.8-11.6) \% \text { protein, } \\
51.7(95 \% \text { CI } 51.2-52.1) \% \text { fat }\end{array}$ & $\begin{array}{l}\text { Mean }(95 \% \mathrm{CI}) \\
\text { (a) } 37.2^{+}(29.5-44.8)^{+} \mathrm{kJ} / \mathrm{h} \\
\text { (b) } 36.8^{+}(30.5-43.0)^{+} \mathrm{kJ} / \mathrm{h} \\
\text { (c) } 30.0^{+}(24.2-35.8)^{+} \mathrm{kJ} / \mathrm{h} \\
\text { * (a vs. b vs. c and a vs. c } \\
\text { for kJ/5 h) }\end{array}$ & $\begin{array}{l}\text { Mean }(95 \% \text { CI): } \\
\text { (a) } 1.4^{\dagger}(1.1-1.7)+\% / h \\
\text { (b) } 1.4^{+}(1.2-1.7)^{+} \% / \mathrm{h} \\
\text { (c) } 1.2^{+}(0.9-1.4)^{+} \% / \mathrm{h}\end{array}$ & $\begin{array}{l}\text { Mean }(95 \% \text { CI }) \\
\text { (a) } 12.3(9.7-14.9) \% \\
\text { (b) } 11.8(9.7-13.9) \% \\
\text { (c) } 9.6(7.7-11.4) \% \\
\text { * (a vs. c and b vs. c } \\
\text { for \%AB) } \\
\text { * (a vs. b vs. c for \% AB) }\end{array}$ & $\begin{array}{l}\text { DIT was significantly higher } \\
\text { in PUFA and MUFA meals } \\
\text { compared to SFA meal. }\end{array}$ \\
\hline $\begin{array}{l}\text { Piers et al. [18] } \\
\text { DIT = open circuit ventilated } \\
\text { hood canopy system for } 5 \mathrm{~h} \text {; } \\
\text { DIT measured for } 30 \mathrm{~min} \\
\text { periods each hour }\end{array}$ & $\begin{array}{l}2500^{+} \mathrm{kJ} \\
42 \% \mathrm{CHO}, 15 \% \text { of energy from } \\
\text { protein, } 43 \% \text { fat }\end{array}$ & $\begin{array}{l}\text { (a) } 29.6^{+}(10)^{+} \mathrm{kJ} / \mathrm{h} \\
\text { (b) } 28.4^{+}(10)^{+} \mathrm{kJ} / \mathrm{h} \\
\text { NS (a vs. b for kJ/5 h) }\end{array}$ & $\begin{array}{l}\text { (a) } 1.2^{+}(0.4)+\% / h \\
\text { (b) } 1.1^{+}(0.4) \% / \mathrm{h} \\
\text { NS (a vs. b for } \% / 5 \mathrm{~h} \text { ) }\end{array}$ & $\begin{array}{l}\text { (a) } 9.5^{+}(3.2)+\% \\
\text { (b) } 9.3^{+}(3.2)^{+} \%\end{array}$ & $\begin{array}{l}\text { No significant differences in } \\
\text { DIT between SFA and } \\
\text { MUFA meals. }\end{array}$ \\
\hline
\end{tabular}


Table 2. Cont.

\begin{tabular}{|c|c|c|c|c|c|}
\hline $\begin{array}{l}\text { Reference and DIT } \\
\text { Measurement }\end{array}$ & $\begin{array}{l}\text { Energy Ingested (kJ) and \% } \\
\text { Energy from Macronutrients }\end{array}$ & DIT (kJ) & $\begin{array}{c}\text { DIT \% Energy Content of } \\
\text { the Meal }\end{array}$ & DIT \% above Baseline & Conclusions \\
\hline \multicolumn{6}{|c|}{ Meals varying in macronutrient composition } \\
\hline $\begin{array}{l}\text { Bendixen et al. [37] } \\
\text { DIT = indirect calorimetry } \\
\text { with open circuit, ventilated } \\
\text { hood for } 5 \text { h continuously } \\
\text { with } 10 \text { min breaks } \\
\text { every hour }\end{array}$ & $\begin{array}{l}4698(550.2)^{+} \mathrm{kJ}, 34 \% \mathrm{CHO}, \\
6 \% \text { protein, } 60 \% \text { fat }\end{array}$ & $\begin{array}{l}\text { (a) } 61.8^{+}(15.2)^{+} \mathrm{kJ} / \mathrm{h} \\
\text { (b) } 72.8^{+}(19.0)^{+} \mathrm{kJ} / \mathrm{h} \\
\text { (c) } 69.2^{+}(11.4)^{+} \mathrm{kJ} / \mathrm{h} \\
\text { (d) } 65^{+}(13.9)^{+} \mathrm{kJ} / \mathrm{h} \\
* \text { (a vs. b vs. c vs. d for kJ/5 h) } \\
* * \text { (a vs. b for kJ } / 5 \mathrm{~h} \text { ) } \\
\text { NS (All other pairwise } \\
\text { comparison apart from a vs. b) }\end{array}$ & 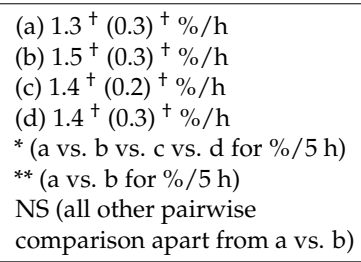 & $\begin{array}{l}\text { (a) } 21.3^{+}(5.2)^{+} \% \\
\text { (b) } 25.1^{+}(6.6)^{+} \% \\
\text { (c) } 23.7^{+}(3.9)^{+} \% \\
\text { (d) } 22.4^{+}(4.8)^{+} \%\end{array}$ & $\begin{array}{l}\text { DIT was significantly higher } \\
\text { in the three modified fat } \\
\text { meals compared to the } \\
\text { conventional fat meal. }\end{array}$ \\
\hline \multicolumn{6}{|c|}{$\begin{array}{l}\text { Processed vs. unprocessed meals } \\
\end{array}$} \\
\hline $\begin{array}{l}\text { Barr and Wright [26] } \\
\text { DIT = indirect calorimetry } \\
\text { using spirometer and } \\
\text { gas bags } \\
\text { (a) } 5.8(0.11) \mathrm{h} \text { (b) } 4.8(0.23) \mathrm{h} \\
2 \text { min measurement by } \\
\text { spirometer followed by } 10 \mathrm{~s} \\
\text { exhalation for } 5 \text { or } 6 \text { breaths } \\
\text { into a gas bag every hour }\end{array}$ & $\begin{array}{l}2520 \text { or } 3360 \mathrm{~kJ} \\
\text { (a) } 39 \% \text { fat, } 40 \% \text { CHO, } 20 \% \\
\text { protein } \\
\text { (b) } \frac{1}{2} \text { sandwich: } 33 \% \text { fat, } 49 \% \\
\text { CHO, } 15 \% \text { protein or } 2 \\
\text { sandwiches: } 33 \% \text { fat, } 50 \% \text { CHO, } \\
15 \% \text { protein }\end{array}$ & $\begin{array}{l}\text { (a) } 99.4^{+}(40.7)^{+} \mathrm{kJ} / \mathrm{h} \\
\text { (b) } 63.9^{+}(35.6)^{\dagger} \mathrm{kJ} / \mathrm{h} \\
* * * \text { (a vs. b kJ/5.8 and } 4.8 \mathrm{~h})\end{array}$ & $\begin{array}{l}\text { (a) } 3.4^{+}(1.7)^{+} \% / \mathrm{h} \\
\text { (b) } 2.2^{+}(1.4)^{+} \% / \mathrm{h} \\
* * \text { (a vs. b\%/5.8 and \%/4.8 h) }\end{array}$ & & $\begin{array}{l}\text { Whole food meal showed a } \\
\text { significant higher DIT } \\
\text { compared to processed meal. }\end{array}$ \\
\hline \multicolumn{6}{|c|}{ Bolus vs. smaller frequent meals } \\
\hline $\begin{array}{l}\text { Kinabo and } \\
\text { Durnin [32]-Paper B } \\
\text { DIT = open circuit indirect } \\
\text { calorimetry using Douglas } \\
\text { bag technique for } 6 \mathrm{~h} \text {; } \\
\text { DIT measured for } 10 \mathrm{~min} \text {, } \\
\text { every } 10 \text { min for the first } \\
90 \text { min and every } 20 \mathrm{~min} \text { for } \\
\text { the last } 90 \mathrm{~min} \text {. }\end{array}$ & $\begin{array}{l}\text { (a and c) } 5040 \mathrm{~kJ} \\
(\mathrm{~b} \text { and d) } 2520 \times 2 \mathrm{~kJ} \\
(\mathrm{a} \text { and b) } 70 \% \mathrm{CHO}, 11 \% \text { protein, } \\
19 \% \text { fat } \\
\text { (c and d) } 24 \% \mathrm{CHO}, 11 \% \text { protein, } \\
65 \% \text { fat }\end{array}$ & $\begin{array}{l}\text { Group A: } \\
\text { (a) } 62.8^{+}(13.2)^{+} \mathrm{kJ} / \mathrm{h} \\
\text { (b) } 63.5^{+}(11.7)^{+} \mathrm{kJ} / \mathrm{h} \\
\text { Group B: } \\
\text { (c) } 59.3^{+}(11.5)^{+} \mathrm{kJ} / \mathrm{h} \\
\text { (d) } 56.7^{+}(8.0)^{+} \mathrm{kJ} / \mathrm{h} \\
\text { NS (a vs. b and c vs. d for kJ/6 h) }\end{array}$ & $\begin{array}{l}\text { Group A } \\
\text { (a) } 1.3^{+}(0.3)^{+} \% / \mathrm{h} \\
\text { (b) } 1.3^{+}(0.2)^{+} \% / \mathrm{h} \\
\text { Group B } \\
\text { (c) } 1.2^{+}(0.25)^{+} \% / \mathrm{h} \\
\text { (d) } 1.1^{+}(0.2)^{+} \% / \mathrm{h}\end{array}$ & $\begin{array}{l}\text { Group A } \\
\text { (a) } 28(6.9)+\% \\
\text { (b) } 31(5.0)+\% \\
\text { Group B } \\
\text { (c) } 27(7.8)^{+} \% \\
\text { (d) } 28(5.1)^{+} \%\end{array}$ & $\begin{array}{l}\text { No significant difference on } \\
\text { DIT between meals consumed } \\
\text { as bolus vs. two smaller } \\
\text { frequent meals. }\end{array}$ \\
\hline $\begin{array}{l}\text { Vaz et al. [34] } \\
\text { DIT = indirect calorimetry for } \\
2 \text { h; DIT measured every } \\
30 \text { min }\end{array}$ & $\begin{array}{l}\text { (a) } 3150^{+} \\
\text {(b) } 1050 \times 3 \mathrm{~kJ}^{+} \\
53.3 \% \mathrm{CHO}, 14.7 \% \text { protein, } \\
32 \% \text { fat }\end{array}$ & $\begin{array}{l}\text { (a) } 71^{+}(31.5)^{+} \mathrm{kJ} / \mathrm{h} \\
\text { (b) } 52.3^{\dagger}(15.3)^{\dagger} \mathrm{kJ} / \mathrm{h} \\
\text { NS }(\text { a vs. b for } \mathrm{kJ} / 2 \mathrm{~h} \text { ) }\end{array}$ & $\begin{array}{l}\text { (a) } 2.3^{+}(1.0)^{\dagger} \% / \mathrm{h} \\
\text { (b) } 1.7^{+}(0.49)^{+} \% / \mathrm{h}\end{array}$ & $\begin{array}{l}\text { (a) } 22.2 \% / \mathrm{h} \\
\text { (b) NP }\end{array}$ & $\begin{array}{l}\text { DIT was lower in the small } \\
\text { frequent feeding regime } \\
\text { compared to one bolus meal } \\
\text { event - but not } \\
\text { significantly different. }\end{array}$ \\
\hline $\begin{array}{l}\text { Allirot et al. [35] } \\
\text { DIT = indirect calorimetry for } \\
4 \text { h; DIT measured for } \\
30 \text { min periods }\end{array}$ & $\begin{array}{l}\text { (a) } 2823.4 \mathrm{~kJ}^{+} \\
\text {(b) total } 2823.4^{+} \text {divided in } \\
705.8^{+} \mathrm{kJ} \mathrm{meals} \\
54.2^{+} \% \text { CHO, } 6.3^{+} \% \text { Protein, } \\
36.7^{+} \% \text { Fat }\end{array}$ & $\begin{array}{l}\text { (a) } 43.8^{\dagger}(18.4)^{+} \mathrm{kJ} / \mathrm{h} \\
\text { (b) } 33.2^{+}(15.5)^{\dagger} \mathrm{kJ} / \mathrm{h}\end{array}$ & $\begin{array}{l}\text { (a) } 1.6^{+}(0.7)^{+} \% / \mathrm{h} \\
\text { (b) } 1.2^{+}(0.6)^{+} \% / \mathrm{h} \\
{ }^{*} \text { (a vs. b for } \% / 4 \mathrm{~h} \text { ) }\end{array}$ & & $\begin{array}{l}\text { DIT was significantly higher } \\
\text { when the meal consumed as } \\
\text { one bolus event compared to } \\
\text { four smaller isocaloric meals } \\
\text { ingested over time in } \\
\text { the morning. }\end{array}$ \\
\hline
\end{tabular}


Table 2. Cont.

\begin{tabular}{|c|c|c|c|c|c|}
\hline $\begin{array}{l}\text { Reference and DIT } \\
\text { Measurement }\end{array}$ & $\begin{array}{l}\text { Energy Ingested (kJ) and \% } \\
\text { Energy from Macronutrients }\end{array}$ & DIT (kJ) & $\begin{array}{l}\text { DIT \% Energy Content of } \\
\text { the Meal }\end{array}$ & DIT \% above Baseline & Conclusions \\
\hline \multicolumn{6}{|c|}{ Bolus vs. smaller frequent meals } \\
\hline $\begin{array}{l}\text { Tai et al. [27] } \\
\text { DIT = indirect calorimetry for } \\
5 \mathrm{~h} \text {; DIT measured every } \\
30 \mathrm{~min}\end{array}$ & $\begin{array}{l}\text { (a) one meal of } 3138 \mathrm{~kJ} \\
\text { (b) } 6 \text { meals of } 523 \mathrm{~kJ} \\
54.5 \% \text { CHO, } 14.0 \% \text { protein, } \\
31.5 \% \text { fat }\end{array}$ & $\begin{array}{l}\text { (a) } 48.2^{+}(16.93)^{+} \mathrm{kJ} / \mathrm{h} \\
\text { (b) } 34.9^{\dagger}(12.3)^{+} \mathrm{kJ} / \mathrm{h} \\
{ }^{*} \text { (a vs. b for kJ/5 } / 5 \text { ) }\end{array}$ & $\begin{array}{l}\text { (a) } 1.5^{+}(0.5)^{+} \% / \mathrm{h} \\
\text { (b) } 1.1^{+}(0.4)^{+} \% / \mathrm{h}\end{array}$ & $\begin{array}{l}\text { (a) } 20.6^{\dagger}(7.2)^{+\%} \% \\
\text { (b) } 14.8^{\dagger}(5.2)^{+} \%\end{array}$ & $\begin{array}{l}\text { DIT was significantly higher } \\
\text { when the meal was consumed } \\
\text { as a one bolus event } \\
\text { compared to six smaller } \\
\text { isocaloric meals ingested over } \\
\text { time in the morning. }\end{array}$ \\
\hline \multicolumn{6}{|c|}{ Fast vs. slow eating patterns } \\
\hline $\begin{array}{l}\text { Hamada et al. [28] } \\
\text { DIT = gas analyzer AE-310S } \\
\text { for } 1.5 \mathrm{~h} \text { continuously }\end{array}$ & $\begin{array}{l}1255.2^{+} \mathrm{kJ}, 42 \% \mathrm{CHO}, 8 \% \text { protein, } \\
50 \% \text { fat }\end{array}$ & $\begin{array}{l}\text { (a) } 19.5^{+}(142.2)^{+} \mathrm{kJ} / \mathrm{kg} / \mathrm{h} \\
\text { (b) } 502.1^{+}(234.4)^{+} \mathrm{kJ} / \mathrm{kg} / \mathrm{h} \\
{ }^{*} \text { (a vs. b for } \mathrm{kcal} / \mathrm{kg} / 90 \mathrm{~min} \text { ) }\end{array}$ & & & $\begin{array}{l}\text { Slowing eating was } \\
\text { associated with a significant } \\
\text { increase in DIT compared to } \\
\text { rapid eating. }\end{array}$ \\
\hline $\begin{array}{l}\text { Toyama et al. [29] } \\
\text { DIT = open-circuit indirect } \\
\text { calorimetry for } 3 \text { h; first hour } \\
\text { continuously, second and } \\
\text { third hours measured for } \\
15 \text { min every } 30 \text { min intervals }\end{array}$ & $\begin{array}{l}1464 \mathrm{~kJ}, 61.3 \% \mathrm{CHO}, 16.4 \% \\
\text { protein, } 22.3 \% \text { fat }\end{array}$ & $\begin{array}{l}\text { (a) } 31.6^{+}(15)^{+} \mathrm{kJ} / \mathrm{kg} / \mathrm{h} \\
\text { (b) } 41.9^{+}(14.6)^{+} \mathrm{kJ} / \mathrm{kg} / \mathrm{h} \\
\mathrm{NS} \text { (a vs. b for } \mathrm{kcal} / \mathrm{kg} / \mathrm{min})\end{array}$ & & $\begin{array}{l}\text { (a) } 6.8(4.8) \% \\
\text { (b) } 8.5(4.2) \%\end{array}$ & $\begin{array}{l}\text { There was no significant } \\
\text { difference in DIT between fast } \\
\text { eating and regular eating. }\end{array}$ \\
\hline \multicolumn{6}{|c|}{ Palatable vs. unpalatable meals } \\
\hline $\begin{array}{l}\text { Sawaya et al. [19] } \\
\text { DIT = ventilated hood } \\
\text { indirect calorimetry, for } 6 \mathrm{~h} \text {; } \\
\text { DIT measured for } 10 \mathrm{~min} \\
\text { with } 5 \text { min breaks for the } 6 \mathrm{~h}\end{array}$ & $\begin{array}{l}2930 \mathrm{~kJ}^{\dagger}, 65 \% \mathrm{CHO}, 12 \% \text { protein, } \\
23 \% \text { fat }\end{array}$ & $\begin{array}{l}\text { (a) old } 37.0^{+}(15.9)^{\dagger} \mathrm{kJ} / \mathrm{h} \\
\text { young } 34.7^{+}(13.6)^{\dagger} \mathrm{kJ} / \mathrm{h} \\
\text { (b) old } 46.4^{+}(18.4)^{+} \mathrm{kJ} / \mathrm{h} \\
\text { young } 39.5^{+}(17.0)^{+} \mathrm{kJ} / \mathrm{h}\end{array}$ & $\begin{array}{l}\text { (a) old } 1.3^{+}(0.5)^{+} \% / \mathrm{h} \\
\text { young } 1.2^{+}(0.5)^{+} \% / \mathrm{h} \\
\text { (b) old } 1.6^{+}(0.6)^{+} \% / \mathrm{h} \\
\text { young } 1.4^{+}(0.6)^{+} \% / \mathrm{h} \\
\text { NS (a vs. b } \% / 3 \mathrm{~h} \text { ) }\end{array}$ & $\begin{array}{l}\text { (a) old } 26.4^{+}(11.3)^{+} \% \\
\text { young } 21.7^{+}(8.5)^{+} \% \\
\text { (b) old } 34.6^{+}(13.7){ }^{+} \% \\
\text { young } 24.8^{+}(10.6)^{+} \%\end{array}$ & $\begin{array}{l}\text { DIT did not significantly } \\
\text { differ between palatable and } \\
\text { unpalatable meals. }\end{array}$ \\
\hline $\begin{array}{l}\text { Weststrate et al. [16] study } 1 \\
\text { DIT = ventilated hood } \\
\text { indirect calorimetry for } \\
3.5 \text { h continuously }\end{array}$ & $\begin{array}{l}2000 \mathrm{~kJ}^{\dagger}, \mathrm{NP} \% \text { energy } \\
\text { from macronutrient }\end{array}$ & $\begin{array}{l}\text { (a) } 47.3^{+}(14.2)^{+} \mathrm{kJ} / \mathrm{h} \\
\text { (b) } 52.9^{+}(13.3)^{+} \mathrm{kJ} / \mathrm{h} \\
\text { NS (a vs. b for } \mathrm{kJ} / 3.5 \mathrm{~h} \text { ) }\end{array}$ & $\begin{array}{l}\text { (a) } 2.4^{+}(0.7){ }^{+} \% / h \\
\text { (b) } 2.6^{+}(0.7)+\% / h \\
\text { NS (a vs. b for } \% / 3.5 \text { h) }\end{array}$ & & $\begin{array}{l}\text { There was not a significant } \\
\text { difference in DIT between } \\
\text { palatable and } \\
\text { unpalatable meals. }\end{array}$ \\
\hline
\end{tabular}

Data are described in mean (SD) unless otherwise described. a, b, c, etc. = these letters describe the types of meal interventions provided as illustrated in Table 1. ${ }^{+}$These data (mean and/or SD and/or 95\% CI) were calculated or converted for one or more of these possible calculations or conversions (DIT \% ECM calculated from DIT kJ, DIT \% above baseline RMR calculated from DIT kJ, DIT kJ calculated from DIT \% ECM, macronutrient \% ECM calculated from grams, kcal converted to kJ, MJ converted to kJ, SE converted to SD, DIT \% ECM or KJ or \% above baseline RMR converted for unit of time, formulas described either in methodology or Supplementary Materials Table S1). ${ }^{++}$Kinabo et al. [31] - paper A is ECM or KJ or \% above baseline RMR converted for unit or tine, formulas described either in methodology or Supplementary Materials Table S1). also part of $\mathrm{RMR}=35 \times 8253.6 \mathrm{~kJ}(24 \mathrm{~h}$ RMR $) / 100$. It is an average value. ${ }^{*} p \leq 0.05 .{ }^{* *} p \leq 0.01 .{ }^{* * *} p \leq 0.001 . \mathrm{BM}=$ Body Mass. DIT = Diet Induced Thermogenesis. CHO $=$ Carbohydrate FFM = Fat Free Mass. LCT $=$ Long Chain Triacylglycerol. MCT $=$ Medium Chain Triacylglycerol. MUFA = Mono Unsaturated Fatty Acids. NS $=$ Not Significant. NP $=$ Not Provided PUFA = Poly Unsaturated Fatty Acids. SFA = Saturated Fatty Acids. $\mathrm{VO}_{2}=$ Rate of Oxygen consumption. 


\subsection{Fast vs. Slow/Normal Meal Consumption}

Two studies [28,29] compared consuming the same isocaloric meal quickly or more slowly. One study [28] compared eating a meal $(1255.2 \mathrm{~kJ})$ as fast as possible to a meal chewed as many times as possible until no lumps remained before swallowing. The other study [29] compared eating a meal (1464 kJ) in $15 \mathrm{~min}$ compared to $5 \mathrm{~min}$. Both studies found a higher DIT when the meal was consumed by slower eating compared to fast eating (slower eating $502.1(234.4) \mathrm{kJ} / \mathrm{kg} / \mathrm{h}$ vs. fast eating $19.5(142.2) \mathrm{kJ} / \mathrm{kg} / \mathrm{h}, p<0.05$ for $\mathrm{kcal} / \mathrm{kg} / 90 \mathrm{~min}$ [28]; slower eating 41.9 (14.6) $\mathrm{kJ} / \mathrm{kg} / \mathrm{h}$ vs. fast eating $31.6(15) \mathrm{kJ} / \mathrm{kg} / \mathrm{h}, p>0.05$ for cal $/ \mathrm{kg} / 180 \mathrm{~min}$ ) [29]), although only one of the studies reached statistical significance [28].

\subsection{Palatable vs. Unpalatable}

Two studies [16,19] compared consuming palatable vs. unpalatable isocaloric meals (2930 kJ [19]; $2000 \mathrm{~kJ}$ [16]) on DIT. There was no significant difference in DIT between these two approaches indicating palatability did not influence DIT. In the first study [19], the effects of palatability were examined in both young and old participants (old participants: palatable meal $37.0(15.9) \mathrm{kJ} / \mathrm{h}$ vs. unpalatable meal $46.4(18.4) \mathrm{kJ} / \mathrm{h}$; young participants: palatable breakfast $34.7(13.6) \mathrm{kJ} / \mathrm{h}$ vs. unpalatable meal 39.5 (17.0) $\mathrm{kJ} / \mathrm{h}, p>0.05 \mathrm{for} \% / 3 \mathrm{~h} \mathrm{ECM})$. In the second study there was also no difference in DIT with palatability (palatable meal $47.3(14.2) \mathrm{kJ} / \mathrm{h}$ vs. unpalatable meal $52.9(13.3) \mathrm{kJ} / \mathrm{h}$, $p>0.05$ for $\mathrm{kJ} / 3 / 5 \mathrm{~h}$ and $\% / 3.5 \mathrm{~h} \mathrm{[16])}$.

\section{Discussion}

This review investigated the effects of meals consumed after an overnight fast that differed in energy content or macronutrient composition on DIT, as well as the effects of consuming the same meal as a single event or multiple small meals or snacks. Studies comparing the effects of differing energy intakes supported a conclusion that a higher energy intake resulted in a higher DIT. This finding was further supported by two meta-regressions (one unadjusted and one adjusted for confounding factors), which found that for every $100 \mathrm{~kJ}$ increase in energy intake, DIT increased by 1.1 (unadjusted) or 1.2 (adjusted) $\mathrm{kJ} / \mathrm{h}$. A number of studies compared the effects of meals differing in macronutrient composition. One study found that a meal high in protein resulted in a higher DIT than meals high in $\mathrm{CHO}$ or fat, and a number of studies suggested that a meal high in $\mathrm{CHO}$ resulted in a higher DIT than a meal high in fat. Medium chain triglyceride meals produced a higher DIT than long chain triglycerides, the effects of mono- and polyunsaturated fats compared to saturated fats were unclear, fat structure (e.g., sunflower oil compared to a chemically structured fat) influenced DIT, and the fat content of a meal had inconsistent effects on DIT. The DIT of meals consumed as two or three small meals did not differ to the DIT of the same meal consumed as a single meal, whereas meals consumed as four to six small meals had a lower DIT compared to the same meals consumed as a single meal. Together these findings indicate that meals consumed after an overnight fast result in a DIT and the magnitude of this DIT is influenced by the energy content, the macronutrient composition, and the eating pattern of the meal.

Five studies investigated the effects of consuming different energy intakes on DIT as a primary outcome $[21-23,31,36]$. The study with the largest sample size found a significant increase in DIT with a higher energy intake [31]. Two studies with much smaller sample sizes reported trends of a higher DIT with a higher energy intake [23,36]. Two other studies [21,22] found no effect on DIT but the small sample sizes (eight and 11) could have impacted these findings. Additionally, one of these two studies provided little difference in energy intake between the two meals consumed [22]. The meta-regressions subsequently undertaken to examine the effect of energy intake on DIT across a much larger range of studies clearly support a conclusion that the energy content of meals consumed after an overnight fast influences DIT. Both the unadjusted meta-regression and the one adjusted for four confounding factors (percentage of males, age, BMI, and duration of DIT measurement) found similar significant 
relationships between a higher energy intake and a higher DIT. The magnitude of the increase in DIT was very small (1.1 or $1.2 \mathrm{~kJ} / \mathrm{h}$ increase with each $100 \mathrm{~kJ}$ increase in energy intake), and whether this increase is clinically meaningful may depend on the magnitude of the energy content of the meal. These findings are consistent with the conclusion of Westerterp that energy intake is a predictor of DIT [41].

A number of studies compared the effects of meals consumed after an overnight fast differing in macronutrient composition. Five studies compared high fat vs. high CHO meals, and four of them found a higher thermogenic effect after the consumption of a high $\mathrm{CHO}$ meal compared to a high fat or moderate fat meal. The two studies that found significant effects had sample sizes of 24 males [33] and 14 males [30]. The other two studies, which were conducted with smaller sample sizes (12 males [25] and six females [20]), showed trends for a higher thermogenic effect of high CHO meals, but they did not provide $p$ values and this limited their conclusions [20,25]. Furthermore, Thyfault et al. [25] compared a high CHO meal with a moderate fat, moderate $\mathrm{CHO}$ meal (45\% fat) and therefore, the moderate $\mathrm{CHO}$ content could have confounded the findings. The one study that reported no significant difference for this high fat vs. high CHO comparison was conducted in 16 females [31]. Significant effects were found in the two studies conducted in males, whereas no significant effect was observed in the study in females, suggesting that males and females may respond differently following the consumption of $\mathrm{CHO}$ and fat meals. The differences in DIT between males and females may result from hormonal and/or body composition differences. Again, more research is needed to clarify these observations.

Two studies investigated the effects of protein on DIT; one found a significant increase in DIT after a high protein meal compared to high $\mathrm{CHO}$ or high fat meals in 19 participants of mixed gender [15]. The other study found a significant increase in DIT when a high protein meal was consumed compared to an adequate protein meal even though this was a small study of only six females [38]. Both studies suggest a high thermogenic effect of protein, however due to the limited numbers of studies, more research is needed to further investigate the thermogenic effect of protein in meals in both males and females, as gender was suggested to have an effect on the studies comparing high $\mathrm{CHO}$ vs. high fat meals $[30,31,33]$.

A review by Tappy et al. [42] supports the higher thermogenic effect of protein compared to fat; this review reported DIT to be $0 \%-3 \%$ for fat, $5 \%-10 \%$ for $\mathrm{CHO}$, and $20 \%-30 \%$ for proteins [42]. The different thermogenic effects of macronutrients are further reinforced by two studies comparing two diet interventions $[43,44]$. One study compared a high protein diet to an adequate protein diet for four days in 12 women and found a significantly higher DIT with the high protein diet (high protein diet 0.91 (0.25) MJ/day or 10.1 (2.7) \% energy intake vs. high fat diet 0.69 (0.24) MJ/day or 7.6 (2.5) \% energy intake, $p<0.05$ ) [43]. Another study compared a high protein diet to a high fat diet for $36 \mathrm{~h}$ in eight women and found a significantly higher $24 \mathrm{~h}$ DIT with the high protein diet intervention as opposed to the high fat diet (high protein diet 1295 (240) kJ/day or 14.6 (2.9) \% energy intake vs. high fat diet 931 (315) kJ/day or 10.5 (3.8) \% energy intake, $p=0.02$ ) [44]. Therefore, the findings of this SR regarding the role of meals differing in fat, $\mathrm{CHO}$ and protein composition on DIT are consistent with other studies investigating the effect of diets varying on macronutrients compositions on DIT. With regard to possible mechanisms of action of the higher thermogenic effect of protein, Westerterp-Plantenga [45] suggests that a higher protein diet may increase protein synthesis, which has a high energy cost, or if protein is oxidized the energy cost is higher than fat or $\mathrm{CHO}$, and energy cost also varies with amino acid composition $[45,46]$.

One study compared higher vs. lower levels of fat intake and found a significant increase in DIT following the consumption of a high fat meal compared to a low fat meal in female participants. This significant effect was only found in the 12 normal weight participants [24] and not in the six overweight or three underweight participants, however the small numbers of participants in the overweight and underweight groups would make finding effects in these groups difficult. Also, the different protein levels of the two meals could have impacted the findings of this study. 
A number of studies compared the effects of different types of fats on DIT whereas no studies were identified that compared the effects of different types of proteins or carbohydrates on DIT. A significantly higher thermogenic effect was found when meals containing MCTs were compared to those containing LCTs; this finding was consistent in the three studies included [14,17]. The meta-analysis combining these three papers confirmed this significant increase in thermogenesis following the consumption of a meal with MCTs compared to LCTs $(p<0.005)$. Two hypotheses have been proposed regarding possible mechanisms by which the higher thermogenic effect of MCTs vs. LCTs might be achieved. One suggests an important role for the liver. MCTs are transported directly to the liver by the portal vein whereas LCTs are transported by the lymphatic system to peripheral tissues (adipose tissue and muscle) [47]. Also, LCTs need to bind to carnitine in order to pass through the mitochondrial membrane of the liver where B-oxidation occurs [47], whereas MCTs do not [48]. Therefore, MCTs being directly transported to the liver and that are easily able to pass through the mitochondrial membrane may be responsible for their higher DIT [49,50].The second hypothesis suggests a role for the sympathetic nervous system. Dullo et al. [51] found increased noradrenaline levels after MCT consumption and the authors suggested that sympathetic nervous system stimulation could therefore be responsible for the increase in energy expenditure of MCTs. Kasai et al. [14] has indicated that more research is needed to support this proposed mechanism.

Inconsistent results were found between two studies that compared different saturation of fat on DIT. The study which found a significantly higher DIT by PUFA and MUFA meals compared to a SFA meal [39] had a much larger sample size (29 participants) than the study which did not find a significant difference between MUFA and SFA meals (14 participants) [18]. More research is needed to clarify these findings. The effects of fat structure were also investigated. One study [37] found that fat structure, specifically meals containing a chemically structured fat, a lipase-structured fat, and physically mixed fat was associated with a significantly higher DIT compared to a conventional type of fat, and the highest DIT was associated with the consumption of the chemically structured fat. These findings are clearly preliminary and more studies are needed to confirm these observations.

One study examined the thermogenic effect of a less processed (e.g., whole grain bread) meal compared to a more processed meal [26] after an overnight fast and found a significantly higher DIT following consumption of the less processed meal. Although energy intake was consistent between trials in the same participant, the sample consisted of males and females, and there were two different caloric options within the study. It is unclear whether the choice of caloric options was controlled for in the analysis or whether there was a gender difference in the choice of caloric option. Furthermore, the macronutrient composition of these two meals differed and could have impacted the findings. Therefore, there is a need for further research comparing the effects of consuming more processed vs. less processed foods with the macronutrient content of the meals closely matched.

Four studies investigated the effects of consuming the same amount of calories and meal composition as a bolus event compared to a number of smaller meals during the morning. Two studies found a significant increase in DIT when the meal was consumed as one meal (bolus) instead of four [35] or six [27] smaller frequent meals. Two other studies did not find a significant difference in DIT between bolus and two [32] or three [34] smaller frequent meals regardless of macronutrient compositions [32,34]. The studies that did not find a significant difference provided less frequent meals for the snacking comparison, resulting in fewer meals with higher energy intake. The meta-analysis conducted on these four studies found that DIT was significantly higher when the meal was consumed as one bolus event. Together these results suggest that fewer larger meals result in a higher DIT than more frequent smaller meals.

Two studies [28,29] found a higher DIT following a meal eaten slowly compared to a meal eaten quickly, although these findings were only significant for one study [28]. The study that found a significant effect was conducted in ten males whereas the study that did not find a significant difference was conducted in nine females [29]. It is possible that gender is a factor influencing these results. Furthermore, these two studies suggest that the time that is spent on chewing the food may 
influence the magnitude of DIT; however more research is needed to clarify this observation and to compare the effects between males and females. Only two studies $[16,19]$ have compared the effects of consuming a palatable versus an unpalatable meal on DIT in 19 males [19] or 12 participants (6 males and 6 females) [16]. Neither study found any significant differences in DIT. Although these findings suggest that palatability has no effect on DIT, the small number of studies limits the ability to draw any firm conclusions on this topic. Finally, it is important to note that no studies identified for this review have investigated the effects of differing micronutrients on DIT and this may potentially be another factor to influence DIT, which therefore warrants further investigation.

\subsection{Strengths of This $S R$}

This SR, including meta-analysis and meta-regression, is the first one to be conducted to investigate the effects of energy intake, macronutrient composition and eating events on DIT. This SR was able to identify and summarize the highest level of evidence available in this area and highlights where more research is needed in this field. The studies included were screened for quality/risk of bias and none of the studies had negative quality. Furthermore, the meta-regression was able to quantify the short-term effects of differing energy intakes after an overnight fast on DIT. In addition, the meta-analyses were able to quantify the influence of MCT vs. LCT and the role of consuming bolus eating events vs. smaller frequent meals in the morning on DIT. Considering the lack of evidence base regarding the role of meals consumed after an overnight fast on obesity prevention, this SR was able to provide evidence of the short-term effect of consuming different types of meals on DIT, which in the long term could play a significant role in obesity.

\subsection{Limitations}

There are a number of limitations regarding this SR. First, the included studies were very heterogeneous, differing in their research questions and the types of meals served after an overnight fast (as summarized in Tables 1 and 2). This heterogeneity limited the meta-analyses that could be conducted and the confidence with which conclusions could be drawn. Furthermore, only meta-analyses with a minimum of three studies were included in this SR.

Secondly, the majority of studies investigating DIT are conducted after an overnight fast even if their primary aim is not to investigate the effect of breakfast per se. These studies met the criteria to be included because they administered meals/snacks (even if not a typical breakfast meal) after an overnight fast (definition of breakfast). Lacking are studies of the effects of meals representative of breakfast in specific cultures. Whether these representative breakfast meals would have a different effect on DIT is unclear.

Thirdly, the studies varied in the units of measurement used to report DIT, including kcal or kJ, $\% \mathrm{ECM}$, or \% above baseline (AB), and this limited the direct comparability of the findings between the studies. In order to address this issue, whenever possible, DIT was converted into units of measurements that allowed direct comparisons (e.g., DIT kJ converted to \% ECM or \% AB). Also, the studies measured DIT for different lengths of time, ranging from one and a half to six hours, and the length of time that the DIT is measured affects the magnitude of DIT detected [12,13,52]. In order to account for this limitation, the data were transformed into $\mathrm{kJ} / \mathrm{h}$ allowing the results to be compared among studies. Furthermore, this confounding factor was adjusted for in the meta-regression model.

There is conflicting evidence about the length of time that DIT needs to be measured to provide accurate results. Two papers have recommended measuring DIT for at least three hours. One conducted a study in ten participants and concluded that $3 \mathrm{~h}$ DIT measurements are sufficient as $76 \%$ of DIT is obtained during this period [52]. The other paper [12] analyzed data from six studies with a total of 103 subjects and also recommended measuring DIT for three hours, as they found that the majority of the DIT was measured by three and a half hours when either high or low energy intakes (ranging from $1.3 \mathrm{MJ}$ to $2.6 \mathrm{MJ}$ ) were consumed and in both men and women [12]. Another study [13] conducted in 131 participants recommended measuring DIT up to six hours, as $3 \mathrm{~h}$ measurements underestimated 
the DIT response by $40 \%$ [13]. Therefore, it is possible that studies included in this review that measured durations of DIT shorter than six hours may have underestimated DIT. In addition, DIT was measured differently in the studies, as some measured DIT for short durations at regular intervals (interval ranges also differed among studies) whereas other studies measured it continuously, which may have affected the magnitude of DIT detected. Specifically, Piers et al. [53] found a significantly $(p<0.01)$ lower DIT when it was measured at intervals compared to continuously in the same five subjects [53]. Most of the studies included in this review measured DIT at intervals and therefore there is a risk that the DIT was underestimated.

The small sample size of the majority of the studies included is another limitation of this SR. Sample sizes ranged from four to 29 participants, which limits the statistical power and capacity to find small but possibly important effects, as well as limiting the generalizability of the findings. This makes similarity of study designs that can be included in meta-analyses and meta-regressions even more important.

The interventions provided in the studies included in the meta-regression on energy intake had substantial variations; for example, they had different macronutrient compositions, and in some instances the meals were administered differently (such as meals consumed as a bolus vs. smaller frequent meals). Furthermore, the studies included in the meta-analyses were few, and even then included some heterogeneity. For example, the studies included in the MCT and LCT meta-analysis had meals with different levels of LCT or MCT. Also, for the bolus vs. smaller frequent meals meta-analysis, the energy intakes differed between the studies included. Furthermore, the smaller frequent meals arm differed in the number of smaller meals provided between the studies (two, three, four and six). All these factors were not possible to be adjusted for and could have impacted the findings of the meta-regressions and meta-analyses.

Furthermore, the meta-analyses were conducted by considering the two groups for comparison as two different groups of people, even though in reality it was the same group of people repeated in cross-over designs. For this reason, the analyses conducted by RevMan used a more conservative approach, because it is more difficult to find statistical significance if two comparison groups consist of different people. However, the heterogeneity between studies is also expected to be underestimated for the same reason. Therefore, for the two meta-analyses conducted in this SR (MCT vs. LCT and meal vs. snacking), the heterogeneities are expected to be larger than the number provided and the $p$ values are also expected to be even more significant (smaller) that the ones provided (in both cases they are already highly significant). The CIs are also believed to be smaller than the ones provided.

Also, in the findings of this SR, meta-regression and meta-analyses were based primarily on studies rated neutral for quality, thereby limiting the confidence with which conclusions could be drawn.

Finally, the included studies were almost entirely short-term (single meal interventions; only one study investigated the effects of 2 weeks of the same meal daily prior to measurement following a single meal) [36], therefore, whether the effects observed reflect, at least in part, the novelty of unfamiliar meals consumed after an overnight fast on DIT is unclear.

It was not possible to draw any conclusions about the effect of a routine breakfast on DIT. Therefore larger, longer-term experimental studies are needed to draw conclusions about these topics. Specifically, there is the need to investigate the long-term effects of regular consumption of low energy intake vs. high energy intake meals and meals varying in macronutrient composition on DIT, and whether these factors ultimately affect total daily energy intake and DIT or the weight of participants. There is also a need to compare the effects of these influences on DIT between regular breakfast eaters and skippers, as this was found to be an important factor to consider by a previous trial conducted in this area [54]. 


\subsection{Recommendations}

Most of the studies included in this SR were rated neutral instead of positive quality because they had not provided enough or clear information about the selection of participants, recruitment, or inclusion and exclusion criteria. Therefore, it is recommended for future studies in this area to provide more information about recruitment, inclusion and exclusion criteria of participants, and any risk of biases in selection of the subjects.

This SR found heterogeneity between studies regarding the length of DIT measured. Therefore, this SR has identified the need for more clarity on how long DIT should be measured in order to provide accurate results, and in order to achieve more homogenous study designs in this field.

This SR also highlights the heterogeneous ways DIT is reported between studies ( $\mathrm{kJ}$ or $\mathrm{kcal}, \%$ of ECM, or \% above baseline RMR). It is recommended that future studies provide DIT in all of these three units of measure ( $\mathrm{kJ}$ or Kcal, \% ECM, and \% above baseline RMR) in order to allow easier comparison with other studies conducted in this field and future meta-analyses.

It is also recommended for future studies to provide the data regarding baseline RMR and energy content provided by the meal, as this will allow a more comprehensive picture of the study design and results.

The majority of the studies had very small sample sizes. It is therefore recommended that future studies either increase the sample size in order to improve the statistical power of the studies, or provide evidence that the sample size used was adequate to detect an effect.

\section{Conclusions}

This systematic review has consolidated the current evidence regarding the effects of variations in energy intake, macronutrient composition, and the pattern of meals consumption after an overnight fast on DIT. It has also identified a substantial number of questions that remain to be answered, and the high level of uncertainty around many of the influences on the effects of meals on DIT. There is an enormous scope for future high quality studies in this field of research. Consensus on the duration of DIT measurement and larger sample sizes are just two ways in which research in this area could be improved. Comparisons of the effects of manipulations of meals consumed after an overnight fast on DIT in males and females, different age groups, and those who are healthy or have a range of obesity-related health conditions would also be informative.

Supplementary Materials: The following are available online at http:/ /www.mdpi.com/2072-6643/8/11/670/s1, Table S1: Formulas used to calculate participants' characteristics, macronutrients compositions, or DIT.

Acknowledgments: This project was supported by the University of Newcastle Postgraduate Research Scholarship Central (UNRSC50:50). The authors wish to acknowledge the contribution of three research assistants: Allison Brandt, Loren Stroud, and Kelly Rice who assisted with the systematic review process and data extraction. The authors wish to thank Debbie Booth, faculty librarian, University Library, the University of Newcastle, for providing assistance with the literature search.

Author Contributions: All authors (A.Q.; R.C.; A.P., L.M.-W.) have made substantial contributions to all of the following: conception and design of the systematic review, systematic review process, acquisition of data, analysis and interpretation of data, drafting the paper, critically revising the review for important intellectual content, and final approval of the version to be submitted.

Conflicts of Interest: The authors declare no conflict of interest.

\section{Abbreviations}

The following abbreviations are used in this manuscript:

$\begin{array}{ll}\text { AB } & \text { Above Baseline } \\ \text { ATP } & \text { Adenosine Triphosphate } \\ \text { BM } & \text { Body Mass } \\ \text { BMI } & \text { Body Mass Index } \\ \text { CHO } & \text { Carbohydrate } \\ \text { CI } & \text { Confidence Interval } \\ \text { ECM } & \text { Energy Content of the Meal }\end{array}$




$\begin{array}{ll}\text { FFM } & \text { Fat Free Mass } \\ \text { FM } & \text { Fat Mass } \\ \text { DIT } & \text { Diet Induced Thermogenesis } \\ \text { LCT } & \text { Long Chain Triglycerides } \\ \text { M } & \text { Male } \\ \text { MCT } & \text { Medium Chain Triglycerides } \\ \text { MUFA } & \text { Mono Unsaturated Fatty Acids } \\ \text { N } & \text { Sample } \\ \text { NPI } & \text { Not Provided Information } \\ \text { NP } & \text { Not Provided } \\ \text { NS } & \text { Not Significant } \\ \text { PUFA } & \text { Poly Unsaturated Fatty Acids } \\ \text { RCT } & \text { Randomized Controlled Trials } \\ \text { REE } & \text { Resting Energy Expenditure } \\ \text { RMR } & \text { Resting Metabolic Rate } \\ \text { SD } & \text { Standard Deviation } \\ \text { SE } & \text { Standard Error } \\ \text { SFA } & \text { Saturated Fatty Acids } \\ \text { SR } & \text { Systematic Review } \\ \text { VO } & \\ & \text { Rate of Oxygen Consumption }\end{array}$

\section{References}

1. Brown, A.W.; Bohan Brown, M.M.; Allison, D.B. Belief beyond the evidence: Using the proposed effect of breakfast on obesity to show 2 practices that distort scientific evidence. Am. J. Clin. Nutr. 2013. [CrossRef] [PubMed]

2. Rampersaud, G.C.; Pereira, M.A.; Girard, B.L.; Adams, J.; Metzl, J.D. Breakfast habits, nutritional status, body weight, and academic performance in children and adolescents. J. Am. Diet. Assoc. 2005, 105, 743-760. [CrossRef] [PubMed]

3. Casazza, K.; Fontaine, K.R.; Astrup, A.; Birch, L.L.; Brown, A.W.; Bohan Brown, M.M.; Durant, N.; Dutton, G.; Foster, E.M.; Heymsfield, S.B.; et al. Myths, presumptions, and facts about obesity. N. Engl. J. Med. 2013, 368, 446-454. [CrossRef] [PubMed]

4. Dietitians Association of Australia (DAA). Breakfast. Available online: http://daa.asn.au/for-the-public/ smart-eating-for-you/nutrition-a-z/breakfast/ (accessed on 19 July 2016).

5. Betts, J.A.; Richardson, J.D.; Chowdhury, E.A.; Holman, G.D.; Tsintzas, K.; Thompson, D. The causal role of breakfast in energy balance and health: A randomized controlled trial in lean adults. Am. J. Clin. Nutr. 2014, 100, 539-547. [CrossRef] [PubMed]

6. Kobayashi, F.; Ogata, H.; Omi, N.; Nagasaka, S.; Yamaguchi, S.; Hibi, M.; Tokuyama, K. Effect of breakfast skipping on diurnal variation of energy metabolism and blood glucose. Obes. Res. Clin. Pract. 2014, 8, e201-e298. [CrossRef] [PubMed]

7. WHO. Overweight and Obesity. Available online: http://www.who.int/gho/ncd/risk_factors/overweight_ text/en/ (accessed on 13 August 2015).

8. Australian Institute of Health and Welfare (AIHW). Overweight and obesity. Available online: http:/ / www. aihw.gov.au/overweight-and-obesity/ (accessed on 19 July 2016).

9. Szajewska, H.; Ruszczynski, M. Systematic review demonstrating that breakfast consumption influences body weight outcomes in children and adolescents in Europe. Crit. Rev. Food Sci. Nutr. 2010, 50, 113-119. [CrossRef] [PubMed]

10. Williams, P.G. The benefits of breakfast cereal consumption: A systematic review of the evidence base. Adv. Nutr. Int. Rev. J. 2014, 5, 636S-673S. [CrossRef] [PubMed]

11. Lean, M.E.J.; Malkova, D. Altered gut and adipose tissue hormones in overweight and obese individuals: Cause or consequence? Int. J. Obes. 2016, 40, 622-632. [CrossRef] [PubMed]

12. Weststrate, J.A. Resting metabolic rate and diet-induced thermogenesis: A methodological reappraisal. Am. J. Clin. Nutr. 1993, 58, 592-601. [PubMed]

13. Reed, G.W.; Hill, J.O. Measuring the thermic effect of food. Am. J. Clin. Nutr. 1996, 63, 164-169. [PubMed]

14. Kasai, M.; Nosaka, N.; Maki, H.; Suzuki, Y.; Takeuchi, H.; Aoyama, T.; Ohra, A.; Harada, Y.; Okazaki, M.; Kondo, K. Comparison of diet-induced thermogenesis of foods containing medium-versus long-chain triacylglycerols. J. Nutr. Sci. Vitaminol. 2002, 48, 536-540. [CrossRef] [PubMed] 
15. Raben, A.; Agerholm-Larsen, L.; Flint, A.; Holst, J.J.; Astrup, A. Meals with similar energy densities but rich in protein, fat, carbohydrate, or alcohol have different effects on energy expenditure and substrate metabolism but not on appetite and energy intake. Am. J. Clin. Nutr. 2003, 77, 91-100. [PubMed]

16. Weststrate, J.A.; Dopheide, T.; Robroch, L.; Deurenberg, P.; Hautvast, J.G. Does variation in palatability affect the postprandial response in energy expenditure? Appetite 1990, 15, 209-219. [CrossRef]

17. Clegg, M.; Golsorkhi, M.; Henry, C. Combined medium-chain triglyceride and chilli feeding increases diet-induced thermogenesis in normal-weight humans. Eur. J. Nutr. 2013, 52, 1579-1585. [CrossRef] [PubMed]

18. Piers, L.S.; Walker, K.Z.; Stoney, R.M.; Soares, M.J.; O'Dea, K. The influence of the type of dietary fat on postprandial fat oxidation rates: Monounsaturated (olive oil) vs. saturated fat (cream). Int. J. Obes. Relat. Metab. Disord. 2002, 26, 814-821. [PubMed]

19. Sawaya, A.L.; Fuss, P.J.; Dallal, G.E.; Tsay, R.; McCrory, M.A.; Young, V.; Roberts, S.B. Meal palatability, substrate oxidation and blood glucose in young and older men. Physiol. Behav. 2001, 72, 5-12. [CrossRef]

20. Bowden, V.L.; McMurray, R.G. Effects of training status on the metabolic responses to high carbohydrate and high fat meals. Int. J. Sport Nutr. Exerc. Metab. 2000, 10, 16-27. [CrossRef] [PubMed]

21. Bennett, C.; Reed, G.W.; Peters, J.C.; Abumrad, N.N.; Sun, M.; Hill, J.O. Short-term effects of dietary-fat ingestion on energy expenditure and nutrient balance. Am. J. Clin. Nutr. 1992, 55, 1071-1077. [PubMed]

22. Segal, K.R.; Edano, A.; Blando, L.; Pi-Sunyer, F.X. Comparison of thermic effects of constant and relative caloric loads in lean and obese men. Am. J. Clin. Nutr. 1990, 51, 14-21. [PubMed]

23. Hill, J.O.; Heymsfield, S.B.; McMannus, C., III; DiGirolamo, M. Meal size and thermic response to food in male subjects as a function of maximum aerobic capacity. Metabolism 1984, 33, 743-749. [CrossRef]

24. Riggs, A.J.; White, B.D.; Gropper, S.S. Changes in energy expenditure associated with ingestion of high protein, high fat versus high protein, low fat meals among underweight, normal weight, and overweight females. Nutr. J. 2007, 6, 40. [CrossRef] [PubMed]

25. Thyfault, J.P.; Richmond, S.R.; Carper, M.J.; Potteiger, J.A.; Hulver, M.W. Postprandial metabolism in resistance-trained versus sedentary males. Med. Sci. Sports Exerc. 2004, 36, 709-716. [CrossRef] [PubMed]

26. Barr, S.B.; Wright, J.C. Postprandial energy expenditure in whole-food and processed-food meals: Implications for daily energy expenditure. Food Nutr. Res. 2010, 54, 1. [CrossRef] [PubMed]

27. Tai, M.M.; Castillo, P.; Pi-Sunyer, F.X. Meal size and frequency: Effect on the thermic effect of food. Am. J. Clin. Nutr. 1991, 54, 783-787. [PubMed]

28. Hamada, Y.; Kashima, H.; Hayashi, N. The number of chews and meal duration affect diet-induced thermogenesis and splanchnic circulation. Obesity 2014, 22, E62-E69. [CrossRef] [PubMed]

29. Toyama, K.; Zhao, X.; Kuranuki, S.; Oguri, Y.; Kashiwa Kato, E.; Yoshitake, Y.; Nakamura, T. The effect of fast eating on the thermic effect of food in young Japanese women. Int. J. Food Sci. Nutr. 2015, 66, 140-147. [CrossRef] [PubMed]

30. Nagai, N.; Sakane, N.; Moritani, T. Metabolic responses to high-fat or low-fat meals and association with sympathetic nervous system activity in healthy young men. J. Nutr. Sci. Vitaminol. 2005, 51, 355-360. [CrossRef] [PubMed]

31. Kinabo, J.L.; Durnin, J.V.G.A. Thermic effect of food in man: Effect of meal composition, and energy content. Br. J. Nutr. 1990, 64, 37-44. [CrossRef] [PubMed]

32. Kinabo, J.L.; Durnin, J.V. Effect of meal frequency on the thermic effect of food in women. Eur. J. Clin. Nutr. 1990, 44, 389-395. [PubMed]

33. Blundell, J.E.; Cooling, J.; King, N.A. Differences in postprandial responses to fat and carbohydrate loads in habitual high and low fat consumers (phenotypes). Br. J. Nutr. 2002, 88, 125-132. [CrossRef] [PubMed]

34. Vaz, M.; Turner, A.; Kingwell, B.; Chin, J.; Koff, E.; Cox, H.; Jennings, G.; Esler, M. Postprandial sympatho-adrenal activity: Its relation to metabolic and cardiovascular events and to changes in meal frequency. Clin. Sci. 1995, 89, 349-357. [CrossRef] [PubMed]

35. Allirot, X.; Saulais, L.; Seyssel, K.; Graeppi-Dulac, J.; Roth, H.; Charrie, A.; Drai, J.; Goudable, J.; Blond, E.; Disse, E.; et al. An isocaloric increase of eating episodes in the morning contributes to decrease energy intake at lunch in lean men. Physiol. Behav. 2013, 110-111, 169-178. [CrossRef] [PubMed]

36. Martin, A.; Normand, S.; Sothier, M.; Peyrat, J.; Louche-Pelissier, C.; Laville, M. Is advice for breakfast consumption justified? Results from a short-term dietary and metabolic experiment in young healthy men. Br. J. Nutr. 2000, 84, 337-344. [CrossRef] [PubMed] 
37. Bendixen, H.; Flint, A.; Raben, A.; Hoy, C.E.; Mu, H.; Xu, E.; Bartels, E.M.; Astrup, A. Effect of 3 modified fats and a conventional fat on appetite, energy intake, energy expenditure, and substrate oxidation in healthy men. Am. J. Clin. Nutr. 2002, 75, 47-56. [PubMed]

38. Petzke, K.J.; Klaus, S. Reduced postprandial energy expenditure and increased exogenous fat oxidation in young woman after ingestion of test meals with a low protein content. Nutr. Metab. 2008, 5. [CrossRef] [PubMed]

39. Casas-Agustench, P.; Lopez-Uriarte, P.; Bullo, M.; Ros, E.; Gomez-Flores, A.; Salas-Salvado, J. Acute effects of three high-fat meals with different fat saturations on energy expenditure, substrate oxidation and satiety. Clin. Nutr. 2009, 28, 39-45. [CrossRef] [PubMed]

40. Prisma. Prisma Flow Diagram. Available online: http://www.prisma-statement.org/PRISMAStatement/ FlowDiagram.aspx (accessed on 21 October 2016).

41. Westerterp, K. Diet induced thermogenesis. Nutr. Metab. 2004, 1, 5. [CrossRef] [PubMed]

42. Tappy, L. Thermic effect of food and sympathetic nervous system activity in humans. Reprod. Nutr. Dev. 1996, 36, 391-397. [CrossRef] [PubMed]

43. Lejeune, M.P.; Westerterp, K.R.; Adam, T.C.; Luscombe-Marsh, N.D.; Westerterp-Plantenga, M.S. Ghrelin and glucagon-like peptide 1 concentrations, 24-h satiety, and energy and substrate metabolism during a high-protein diet and measured in a respiration chamber. Am. J. Clin. Nutr. 2006, 83, 89-94. [PubMed]

44. Westerterp, K.R.; Wilson, S.A.; Rolland, V. Diet induced thermogenesis measured over $24 \mathrm{~h}$ in a respiration chamber: Effect of diet composition. Int. J. Obes. Relat. Metab. Disord. 1999, 23, 287-292. [CrossRef] [PubMed]

45. Westerterp-Plantenga, M.S. Protein intake and energy balance. Regul. Pept. 2008, 149, 67-69. [CrossRef] [PubMed]

46. Tessari, P.; Kiwanuka, E.; Zanetti, M.; Barazzoni, R. Postprandial body protein synthesis and amino acid catabolism measured with leucine and phenylalanine-tyrosine tracers. Am. J. Physiol. Endocrinol. Metab. 2003, 284, E1037-E1042. [CrossRef] [PubMed]

47. Bach, A.C.; Babayan, V.K. Medium-chain triglycerides: An update. Am. J. Clin. Nutr. 1982, 36, 950-962. [PubMed]

48. Odle, J. New insights into the utilization of medium-chain triglycerides by the neonate: Observations from a piglet model. J. Nutr. 1997, 127, 1061-1067. [PubMed]

49. Seaton, T.B.; Welle, S.L.; Warenko, M.K.; Campbell, R.G. Thermic effect of medium-chain and long-chain triglycerides in man. Am. J. Clin. Nutr. 1986, 44, 630-634. [PubMed]

50. Berry, M.N.; Clark, D.G.; Grivell, A.R.; Wallace, P.G. The contribution of hepatic metabolism to diet-induced thermogenesis. Metabolism 1985, 34, 141-147. [CrossRef]

51. Dulloo, A.G.; Fathi, M.; Mensi, N.; Girardier, L. Twenty-four-hour energy expenditure and urinary catecholamines of humans consuming low-to-moderate amounts of medium-chain triglycerides: A dose-response study in a human respiratory chamber. Eur. J. Clin. Nutr. 1996, 50, 152-158. [PubMed]

52. Ruddick-Collins, L.C.; King, N.A.; Byrne, N.M.; Wood, R.E. Methodological considerations for meal-induced thermogenesis: Measurement duration and reproducibility. Br. J. Nutr. 2013, 110, 1978-1986. [CrossRef] [PubMed]

53. Piers, L.S.; Soares, M.J.; Makan, T.; Shetty, P.S. Thermic effect of a meal. 1. Methodology and variation in normal young adults. Br. J. Nutr. 1992, 67, 165-175. [CrossRef] [PubMed]

54. Schlundt, D.G.; Hill, J.O.; Sbrocco, T.; Pope-Cordle, J.; Sharp, T. The role of breakfast in the treatment of obesity: A randomized clinical trial. Am. J. Clin. Nutr. 1992, 55, 645-651. [PubMed]

(C) 2016 by the authors; licensee MDPI, Basel, Switzerland. This article is an open access article distributed under the terms and conditions of the Creative Commons Attribution (CC-BY) license (http://creativecommons.org/licenses/by/4.0/). 